\title{
Remanding Without Vacating Agency Action
}

\author{
Brian S. Prestes
}

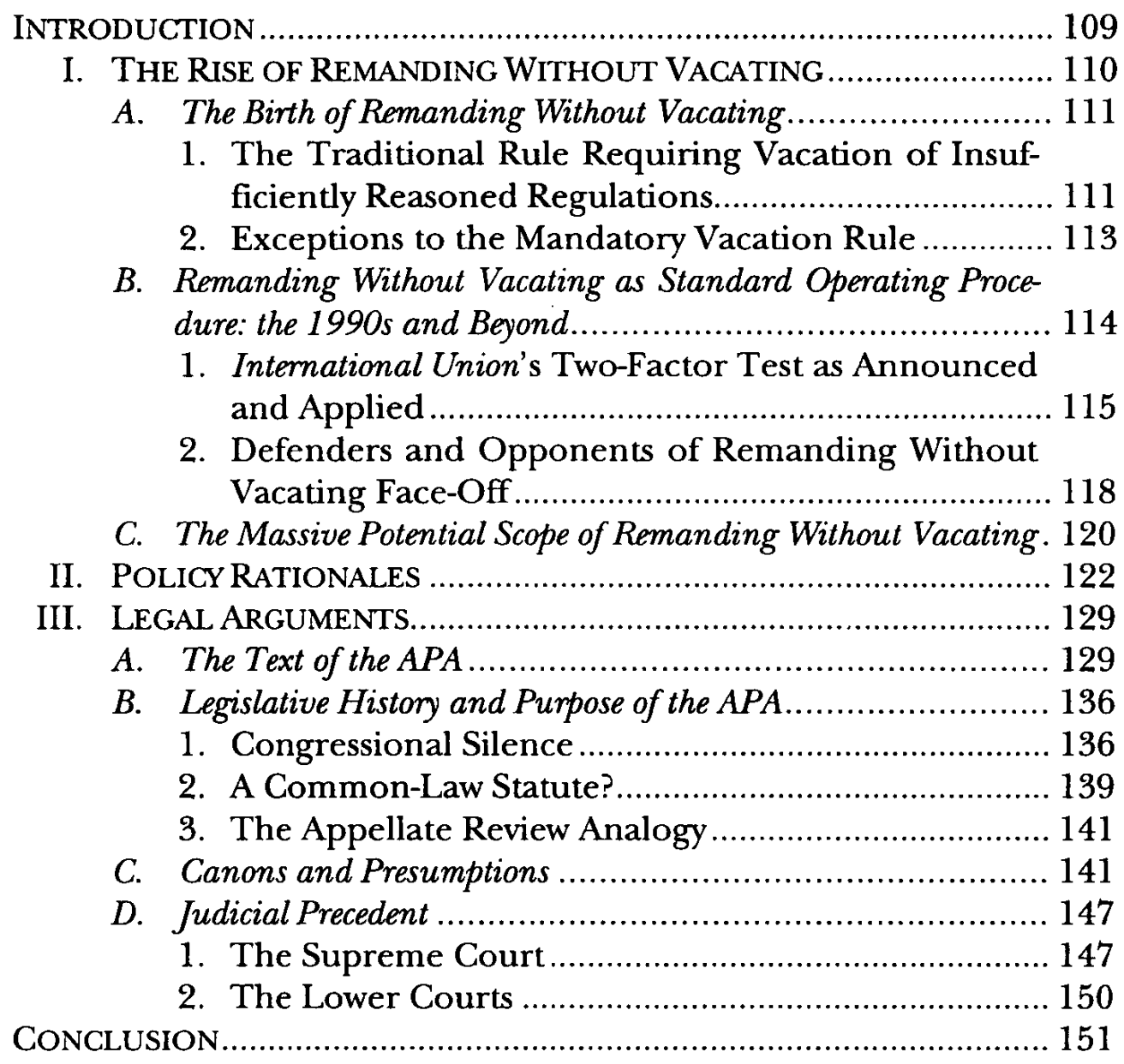

* B.A. 1997, Wake Forest University; J.D. 2001, The University of Chicago Law School. Special thanks to Cass Sunstein and Adrian Vermeule for helpful comments and suggestions. I am also grateful to Michael Edney and Grey Mead for comments on a previous draft. 
In the last decade, courts reviewing agency action have increasingly opted to remand the challenged regulation to the agency without vacating. This trend is likely to continue or accelerate. Because courts' ability to remand without vacating agency action effectively bars relief from successfully challenged regulations, whether remanding without vacating is lawful is a critical question for regulated parties, courts, lawmakers, and agencies alike. This Article suggests that remanding without vacating arbitrary or insufficiently reasoned agency action is unlawful. After arguing that the ambiguous practical benefits of remanding without vacating do not justify brushing the legal arguments aside, this Article concludes, against the conventional wisdom, that the text of the Administrative Procedure Act, along with the legislative history, statutory purpose, canons of construction, and judicial precedent demonstrate the illegality of remanding without vacating.

\section{INTRODUCTION}

Traditionally, courts have vacated federal administrative agency action found to be insufficiently reasoned or arbitrary. In the last decade, however, courts have increasingly opted for an intermediate disposition: remanding the challenged regulation to the promulgating agency to give the agency additional opportunity to justify its action legally without vacating the regulation. Remanding without vacating is on the rise, and the trend is likely to continue or accelerate. But regardless of current trends, the vast majority of insufficiently reasoned agency action is potentially subject to remand without vacation. Therefore, assessing the doctrine's legality has practical value.

The legality of this practice is unclear and the stakes are high. Whether remanding without vacating is legal is a critical question for courts, lawmakers, agencies, and regulated parties challenging agency action. For courts, the legality of this disposition determines whether they must invalidate insufficiently reasoned regulations or whether they may instead return them to the agency for further explanation. The distinction significantly impacts the scope of remedies available to the court. For Congress, whether its statutory command, codified in the Administrative Procedure Act (APA), that courts "shall ... hold unlawful and set aside agency action ... found to be ... arbi-

\footnotetext{
1 5 U.S.C. $\$ \S 551-59,701-06$ (1994).
} 
trary," requires vacation of insufficiently reasoned agency action bears acutely on the strength of the procedural checks central to the constitutionally acceptable existence of administrative agencies. For agencies, the potential for remand without vacation determines whether insufficiently reasoned regulations will be returned to the agency for a second chance at providing a justification, or simply vacated, forcing the agency to start over. Finally, for countless regulated parties, the courts' ability to remand without vacating acts to stay relief from successfully challenged regulations, ${ }^{3}$ and so the legality of this remedy determines whether litigants who have demonstrated the illegality of agency actions will be awarded meaningful relief or instead subjected to the regulations while the agency attempts to repair its rationale.

This Article concludes that remanding without vacating arbitrary agency action is unlawful. Part I documents the rise of remanding without vacating: the practice has evolved from a rare exception to common practice. This Part then argues that, regardless of current trends in the courts, the remand without vacating disposition is worthy of further scrutiny because of its potentially broad scope. Part II rebuts the argument that the dubious legality of remanding without vacating should be overlooked in light of its practical benefits. The point is not that remanding without vacating is unambiguously bad policy. Rather, this Part explains that the policy arguments in the remanding without vacating debate point in different directions and that such ambiguous practical benefits do not justify brushing the legal arguments under the rug. Part III, the focus of the Article, discusses the legal challenges to remanding without vacating. While recognizing substantial arguments in the other direction, this Part concludes that the text of the APA, along with the legislative history and purpose of the APA, canons of construction, and judicial precedent demonstrate the illegality of remanding without vacating arbitrary agency action.

\section{ThE RISE OF REMANDING Without VACATING}

Although widely accepted by courts of appeals, remanding without vacating has a shaky legal pedigree. Commentators have noted the rapid evolution of remanding without vacating from a rare excep-

25 U.S.C. $\$ 706$ (1994).

3 See Ronald M. Levin, "Vacation at Sea: Judicial Remands and the APA," 21 ADMIN. \& REG. L. NEws 4, 5 (Spring 1996) (stating that "[t]he effect of [remanding without vacating] may be to deny any meaningful relief to a litigant who has demonstrated that an agency action is unlawful"). 
tion to common practice:

[I]n only five years, the D.C. Circuit has transformed the expediency of remand without reversal into standard operating procedure. It arose from a split panel decision (Checkosky I) that did not even cite the U.S. Supreme Court precedent (Florida Power $\mathcal{E}^{\circ}$ Light Co. v. Lorian) that would retroactively be deemed central to its reasoning .... It was "the issue discussed but not decided" for a short while, but it then became "a longstanding practice" and even one of the "bedrock principles of administrative law . . . "4

The following discussion documents the development of remanding without vacating. Part I.A explains the traditional remedy of mandatory vacation employed by a reviewing court faced with agency action unsustainable on the record. It then notes that remanding without vacating was, at one point, a rare exception to this baseline remedy. Part I.B discusses the widespread current practice of remanding without vacating. Although it is safe to say that remanding without vacating is standard operating procedure, the reader should get a sense that, contrary to conventional wisdom, remanding without vacating is not settled law-at best it is still settling. Finally, Part I.C argues that, regardless of current trends, the potential scope of remanding without vacating is broad-given current doctrine, courts are able to remand without vacating just about any potentially arbitrary agency action. 5

\section{A. The Birth of Remanding Without Vacating}

1. The Traditional Rule Requiring Vacation of Insufficiently Reasoned Regulations

Prior to the advent of remanding without vacating, the uncontroversial rule was that a reviewing court, finding agency action unsustainable on the record, must vacate the unlawful action. "Until

${ }^{4}$ Frank H. Wu \& Denisha S. Williams, Remand Without Reversal: An Unfortunate Habit, 30 ENVTL. L. REP. 10193 (March 2000) (internal citations omitted). But see Patricia M. Wald, Judicial Review in Midpassage: The Uneasy Partnership Between Courts and Agencies Plays on, 32 TULSA L.J. 221, 236 (1996) (noting that "[w] hether [remanding without vacating] is a legitimate course of conduct for the court to take is still an unsettled question in [the D.C.] Circuit").

${ }^{5}$ For a discussion of the distinction between arbitrary and potentially arbitrary agency action, see infra text accompanying notes 139-149.

6 "Until recently [vacation as a matter of course] . . . has been generally accepted and relatively uncontroversial." ABA, Section of Administrative Law and Regulatory Practice and Business Law, Report to the House of Delegates 1, 1 (1997). See, e.g., Midtec Paper Corp. v. United States, 857 F.2d 1487, 1497 (D.C. Cir. 1988) (stating that "[p]ursuant to the Administrative Procedure Act, courts are instructed always to 
the 1990 s, a reviewing court routinely vacated and remanded an agency rule if the court held the rule arbitrary and capricious because of the agency's failure to . . engage in reasoned decisionmaking."

The 1975 case of National Nutritional Foods Ass'n and Solgar Co. $v$. Weinberger, ${ }^{8}$ is a typical example of mandatory vacation. In National Nutritional Foods, the court addressed a challenge by manufacturers and distributors of vitamins to a Food and Drug Administration (FDA) rule that classified certain vitamins as prescription drugs. ${ }^{9}$ Noting "the agency's obligation to publish a statement of reasons that will be sufficiently detailed to permit judicial review," that under the "arbitrary and capricious" standard of APA section $706^{11}$ "agency action will not be upheld where inadequacy of explanation frustrates review."12 Quoting Camp $v$. Pitts, ${ }^{13}$ the court concluded that " $[w]$ here the agency's finding is not sustainable on the administrative record made, then the ... decision must be vacated and the matter remanded to [the agency] for further consideration."14

'hold unlawful and set aside action, findings, and conclusions found to be ... arbitrary or capricious"). See also KenNeTh Culp Davis \& Richard J. Pierce, JR., Administrative LAW Treatise $\$ 7.4$ (3d ed. 1994).

7 Richard J. Pierce, Jr., Seven Ways to Deossify Agency Rulemaking, 47 ADMIN. L. REV. 59, 75 (1995), quoted in Richard L. Revesz, Ideology, Collegiality, and the D.C. Circuit: A Reply to Chief Judge Harry T. Edwards, 85 VA. L. REv. 805, 819-20 (1999).

512 F.2d 688 (2d Cir. 1975).

9 Id. at 691 .

10 Id. at 701.

115 U.S.C. $\$ 706$ (1994).

12512 F.2d at 701, citing Camp v. Pitts, 411 U.S. 138 (1973); Citizens to Preserve Overton Park v. Volpe, 401 U.S. 402 (1971).

13411 U.S. 138 (1973).

14512 F.2d at 701 (quoting Camp, 411 U.S. at 143) (emphasis added). Because the appellate court in National Nutritional Foods did not have the "entire record that formed the basis of the FDA's classification" before it, the court remanded the case to the district court to determine, "upon the entire administrative record before the Commissioner," whether the FDA acted unlawfully. 512 F.2d at 702-03. This detail is important. Some courts have cited National Nutritional Foods in support of remanding without vacating. See, e.g., Indep. U.S. Tanker Owners Comm. v. Dole, 809 F.2d 847, 854 (D.C. Cir. 1987); United Mine Workers of Am., Int'l Union v. Dole, 870 F.2d 662, 674 (D.C. Cir. 1989) (citing National Nutritional Foods with a parenthetical stating: "remand and not vacatur of regulations [is] appropriate where indications are that agency made rational choice but failed to fully include rationale in record"). But $\mathrm{Na}$ tional Nutritional Foods does not support such a disposition because the court in $\mathrm{Na}$ tional Nutritional Foods remanded the case to the district court, not to the agency. In support of this reading of the case, and of the argument that the case does not provide precedential support for remanding to the agency without vacating, see Checkosky v. SEC, 23 F.3d 452, 493 n.36 (D.C. Cir. 1994) (Randolph, J.) ("The Second Circuit's decision [in National Nutritional Foods] does not support the proposition for which it was invoked [in Independent U.S. Tanker Owners]. The court in National Nutritional Foods remanded the case not to the agency, but to the district court so that it 
2. Exceptions to the Mandatory Vacation Rule

In some early cases courts did remand agency action without vacating. Exceptions to the rule were sometimes invoked in order to avoid particularly undesirable consequences of strictly applying the rule. Rodway $v$. USDA $A^{15}$ demonstrates such an exception to the mandatory vacation rule. In Rodway the court held that the United States Department of Agriculture (USDA) "failed to comply with the procedural command of the APA in promulgating allotment regulations for the food stamp program." ${ }^{\prime 6}$ The court, however, did not vacate the agency's allotment regulations. ${ }^{17}$ Recognizing "the critical importance of the allotment regulations to the functioning of the entire food stamp program," the court left the regulations in effect "until validly promulgated regulations c[ould] take their place." ${ }^{18}$ The court then remanded the case to the district court with instructions to return it to the Secretary of the USDA for a new rule-making procedure to be completed within 120 days. ${ }^{19}$

Five years later, the court in Western Oil and Gas Ass' $n$ v. EPA ${ }^{20}$ issued a similar ruling. ${ }^{21}$ The court found that the Environmental Protection Agency (EPA) had failed to comply with the APA's notice and comment ${ }^{22}$ requirements. ${ }^{23}$ The court noted the general rule: failure to comply with the APA invalidates a regulation. ${ }^{24}$ The court, however, for fear of "thwarting in an unnecessary way the operation of the Clean Air Act ... during the time the deliberative process is reenacted," and in order to avoid unpredictable "undesirable consequences ... that might result from invalidation," left the unlawfully promulgated regulations in effect. ${ }^{25}$ The court cited the "unusual circumstances" of the case along with the court's "discretion to shape an

could determine whether the agency had acted arbitrarily."). Note also that the Independent U.S. Tanker Owners case does not even address the APA section 706(2)(A) question, and, for this reason as well, does not support the practice of remanding without vacating under the APA.

${ }_{15} 514$ F.2d 809 (D.C. Cir. 1975).

16 Id. at 817.

${ }_{17}$ Id. at $817,824$.

18 Id. at 817 .

19 Id. at $818,824$.

633 F.2d 803 (9th Cir. 1980).

Id. at 812.

5 U.S.C. $\$ 553$ (b) (3) (B) (1994).

Western Oil, 633 F.2d at 812.

24

25

Id. at 813 .

Id. 
equitable remedy" as authority for its decision to remand without vacating. ${ }^{26}$

These dispositions, however, were recognized by the rendering courts as narrow exceptions to the traditional rule ${ }^{27}$ that inadequately explained regulations must be vacated. Exceptions to the rule requiring vacation occurred infrequently; they were a rare departure from the general rule of vacating insufficiently reasoned regulations. "Courts departed from use of the vacation and remand remedy only in unusual circumstances, e.g., a court would decline to vacate a rule that was scheduled to expire by its terms in a few months anyway."28 Furthermore, in most, if not all, of the instances in which remanding without vacating did occur prior to 1990 , the reviewing court did not address the question of whether this disposition was permitted by APA section 706(2) (A) ${ }^{29}$ For this reason, many of the early cases in which agency regulations were remanded without being vacated provide little precedential support for the legality of remanding without vacating under the APA. ${ }^{30}$

\section{B. Remanding Without Vacating as Standard Operating Procedure: the 1990s and Beyond}

The remand without vacation remedy began gaining ground in the 1990s as the D.C. Circuit increasingly departed from the mandatory vacation rule in favor of this alternate remedy. ${ }^{31}$ Accordingly, the D.C. Circuit began to flesh out the reasoning behind the remand without vacation disposition. ${ }^{32}$ In International Union, United Mine

26 Id.

27 See Part I.A.1.

28 Pierce, supra note 7, at 75, citing Maryland People's Counsel v. FERC, 768 F.2d 450, 452, 455 (D.C. Cir. 1985) (finding FERC's order authorizing a special marketing program to be "infected by a failure to come to grips with highly relevant considerations," but allowing the order to stand for three months, until its already scheduled expiration, so that it could "die a natural death").

29 See, e.g., United Mine Workers, 870 F.2d at 673-74 (finding regulations "arbitrary and capricious" and, without mention of section 706, discussing vacation as optional).

30 See Webster v. Fall, 266 U.S. 507, 511 (1925) (holding that "[q]uestions which merely lurk in the record, neither brought to the attention of the court nor ruled upon, are not to be considered as having been so decided as to constitute precedents"); Grant v. Shalala, 989 F.2d 1332, 1341 (3d Cir. 1993) (holding that questions not raised but apparently decided are "inconsequential for precedential purposes").

31 Pierce, supra note 7 , at 75.

32 If the discussion appears focused on the D.C. Circuit, this is because the D.C. Circuit handles more than 20 percent of agency appeals, Wald, supra note 4, at 232, and because the legal debate has occurred primarily in the D.C. Circuit. 
Workers of America v. Federal Mine Safety and Health Administration, ${ }^{33}$ the D.C. Circuit announced a two-factor test for remanding without vacating inadequately reasoned agency action. The two relevant factors are (1) "the seriousness of the order's deficiencies" ${ }^{34}$ and (2) "the disruptive consequences of an interim change that may itself be changed. ${ }^{35}$ The court applied this two-factor test in cases such as Massachusetts $v$. $N R C{ }^{36}$ ICORE, Inc. v. FCC, ${ }^{37}$ and Allied-Signal, Inc. v. $N R C^{38}$ and squarely confronted its legality in Checkosky v. SEC. ${ }^{39}$

\section{Intermational Union's Two-Factor Test as Announced and Applied}

In International Union, ${ }^{40}$ the court remanded without vacating an order of the Federal Mine Safety and Health Administration (FMSHA) granting an exception to a mine air flow regulation. ${ }^{41} \mathrm{Al}-$ though the court held that the Assistant Secretary "did not adequately resolve three issues necessary for fulfillment of his duty of reasoned decisionmaking," ${ }^{, 2}$ the court noted the "common[]" practice of remanding without vacating where the agency has failed to engage in reasoned decisionmaking. ${ }^{43}$ As relevant factors, the court noted (1) "the seriousness of the order's deficiencies (and thus the extent of doubt whether the agency chose correctly)"; ${ }^{44}$ and (2) "the disruptive consequences of an interim change that may itself be changed." 45 Explaining that the record did "not appear to speak to the effects of an interim change," the court held that, because it had

920 F.2d 960 (D.C. Cir. 1990)

Id. at 967 .

35 Id.

36924 F.2d 311 (D.C. Cir. 1991).

37985 F.2d 1075 (D.C. Cir. 1993).

38988 F.2d 146 (D.C. Cir. 1993).

3923 F.3d 452 (D.C. Cir. 1994).

40 Int'l Union, United Mine Workers of Am. v. Fed. Mine Safety \& Health Admin., 920 F.2d 960 (D.C. Cir. 1990).

${ }^{41}$ Id. at $962,966-67$.

42 Id. at 965 . See also id. at 966 ("We have found that [the Assistant Secretary's] disposition fails to give an adequate treatment of certain issues, i.e., shows a want of reasoned decisionmaking.").

43 Id. at 966 (citing United Mine Workers of Am., Int'l Union v. Dole, 870 F.2d 662, 673-74 (D.C. Cir. 1989); Maryland People's Counsel v. FERC, 768 F.2d 450, 455 (D.C. Cir. 1985)).

44 Int'l Union, 920 F.2d at 967.

45 Id. (comparing factors relevant to the appropriateness of remanding without vacating with factors relevant to granting a preliminary injunction). 
no reason to believe that the deficiencies of the agency's order would prove fatal, remanding without vacating was the appropriate disposition. $^{46}$

The court in Massachusetts $v . N R C^{47}$ echoed the reasoning in International Union, holding that vacation is unnecessary where the rationale for remanding is "a lack of reasoned decisionmaking." ${ }^{.48}$ Massachusetts $v$. NRC involved a challenge to the Nuclear Regulatory Commission's (NRC) authorization of a license for the Seabrook Nuclear Power Station. ${ }^{49}$ The court reviewed the state's claim that the NRC improperly granted the power plant's low power license without conducting an adjudicatory hearing on potential flaws in the plant's emergency plan..$^{50}$ Because the court was unable to determine, based on the record, whether the NRC had properly considered the state's arguments regarding the plant's emergency response plan, the court remanded to the agency "for reasoned decisionmaking." Although the court held that the agency had failed to explain itself, it "allow[ed] the operating licenses for Seabrook to remain effective." ${ }^{, 52}$

Citing International Union, the court reasoned that "[i]n appropriate cases, we will remand without vacating an agency's order where the reason for the remand is a lack of reasoned decisionmaking." ${ }^{33}$ Quoting International Union, the court noted that the two factors relevant to a decision whether to vacate are "the seriousness of the order's deficiencies.... and the disruptive consequences of an interim change." 54

By 1993, the D.C. Circuit was willing to express its confidence in the appropriateness of remanding without vacating agency actions. Noting that " $[t]$ his and other federal circuit courts have repeatedly found it appropriate to remand an agency action without vacating it," ${ }^{\text {"5 }}$ the court in ICORE ${ }^{56}$ expeditiously disposed of a challenge to its

46 Id.

47924 F.2d 311 (D.C. Cir. 1991).

$48 I d$. at 336.

$49 I d$. at 315 .

50 $I d$.

51 Id. at $315,337$.

$52 I d$ at 315.

53924 F.2d at 336.

54 Id.

55 ICORE, Inc. v. FCC, 985 F.2d 1075, 1081-82 (D.C. Cir. 1993) (citing Massachusetts v. NRC, 924 F.2d 311 (D.C. Cir. 1991); Int'l Union, United Mine Workers of Am. v. Fed. Mine Safety \& Health Admin., 920 F.2d 960 (D.C. Cir. 1990); Rodway v. USDA, 514 F.2d 809 (D.C. Cir. 1975); Western Oil \& Gas Ass'n. v. EPA, 633 F.2d 803 (9th. Cir. 1980)).

56985 F.2d 1075 (D.C. Cir. 1993). 
previous decision in City of Brookings Municipal Telephone Co. v. FCC, ${ }^{57}$ which had remanded without vacating an FCC regulation. ${ }^{58}$

The D.C. Circuit continued the trend in favor of remanding without vacating agency action in Allied-Signal. ${ }^{59}$ In Allied-Signal the court held that a NRC rule allocating its costs among those receiving the NRC's services failed the requirement of reasoned decisionmaking. ${ }^{60}$ The NRC is authorized by Congress to recover 100 percent of its costs from those receiving a "service or thing of value" from the Commission. ${ }^{61}$ The Commission is required to apportion these fees "fairly and equitably" among those receiving its services and, " $[t] o$ the maximum extent practicable, the charges shall have a reasonable relationship to the cost of providing regulatory services." ${ }^{\text {"2 }}$

Allied-Signal argued that the Commission acted arbitrarily and in violation of the statutory mandate to apportion costs "fairly and equitably" by refusing to consider Allied-Signal's inability to pass on fees to its consumers by raising prices. ${ }^{63}$ Because the NRC had exempted nonprofit educational institutions from fees in part on the rationale that they could not pass their costs on to consumers, the court rejected the NRC's argument that it was not reasonable to assess the ability of other regulated parties to pass through costs. ${ }^{64} \mathrm{Be}$ cause the NRC acted on educational institutions' inability to pass through costs but refused to consider Allied-Signal's inability to pass through costs, the court concluded that "the Commission's denial of relief ..., both at the rulemaking and the exemption stages, cannot be viewed as reasonable decision-making." ${ }^{65}$ The court then refused

57822 F.2d 1153, 1171 (D.C. Cir. 1987) (finding that the FCC had failed "to demonstrate a rational basis" for regulation but refusing to vacate in light of the court's lack of expertise in the "technical intricacies" involved and the potential disruptiveness of vacation).

58 ICORE, 985 F.2d at 1081-82. The ICORE court also dispelled any notion that the Supreme Court's holding in Bowen v. Georgetown University Hospital 488 U.S. 204 (1988), which prohibited retroactive rulemaking, counseled against remanding without vacating. ICORE, 985 F.2d at 1082. The court noted that although Georgetown might prevent a court from using retroactive rulemaking "to cure a gap created by judicial vacatur of a rule," it does not prevent courts from remanding without vacating in order to avoid creating these gaps in the first instance. Id. See also infra text accompanying notes $97-99$.

59 Allied-Signal v. NRC, 988 F.2d 146 (D.C. Cir. 1993). For further discussion of Allied-Signal's potentially expansive rationale, see infra notes 86-99.

60 Id. at 150 .

6142 U.S.C. $\$ 2214$ (1994).

6242 U.S.C. $\$ 2214(\mathrm{c})(3)$.

63988 F.2d at 149.

64 Id. at 150.

65 Id. 
to vacate the NRC's rule, noting that "[ $[\mathrm{a}] \mathrm{n}$ inadequately supported rule need not necessarily be vacated." ${ }^{.66}$

The preceding cases flesh out the rule, announced in Intermational Union, ${ }^{67}$ that courts, where the agency has failed to engage in reasoned decisionmaking, ${ }^{68}$ may remand without vacating after considering "the seriousness of the order's deficiencies" 69 and "the disruptive consequences of an interim change that may itself be changed. ${ }^{70}$ By articulating a clear rule permitting courts to remand without vacating inadequately reasoned regulations, the International Union line of cases set the stage for Checkosky $v$. $S E C,{ }^{71}$ the most indepth judicial treatment of the legality of the remand without vacating disposition to date.

2. Defenders and Opponents of Remanding Without Vacating Face-Off

The most thorough judicial discussion of remanding without vacating occurred in the 1994 Checkosky ${ }^{72}$ case. Checkosky involved accountants' petitions for review of a Securities and Exchange Commission (SEC) order suspending them for "improper professional conduct." ${ }^{173}$ Although the SEC had specified that bad faith was not a prerequisite to a finding of improper professional conduct sufficient to suspend the accountants' licenses, the agency had failed to specify what state of mind was necessary. ${ }^{74}$ The D.C. Circuit denied the accountants' request for relief and remanded the case to the SEC for "a more adequate explanation of its interpretation of [the relevant] Rule ... and its application to [the] case." 75 Specifically, the court remanded for the SEC to specify and justify the standard of conduct it applied to the petitioners. ${ }^{76}$

Although the court's disposition in Checkosky, remanding the case to the SEC without vacating the order, represented the "least

\footnotetext{
${ }^{66} I d$.

67920 F.2d 960 (D.C. Cir. 1990).

${ }^{68} I d$. at 966.

${ }^{69} I d$. at 967.

70 Id.

7123 F.3d 452 (D.C. Cir. 1994) (disposing of the case per curiam with Judges Silberman and Randolph writing separate opinions and Judge Reynolds filing a separate opinion concurring in part and dissenting in part).

72 Id.

73 Id. at 454.

${ }_{75} I d$. at 458 (Silberman, J.).

75 Id.

${ }^{76}$ Id. at 456.
} 
common denominator" 77 between the deciding judges, Judge Randolph and Judge Silberman sharply disagreed over the court's duty to vacate as well as remand the SEC's order. ${ }^{78}$ Each judge wrote a separate opinion, in Judge Silberman's case defending, ${ }^{79}$ and in Judge Randolph's case attacking, ${ }^{80}$ the remand without vacating disposition. Although Judge Randolph put up a good fight, Judge Silberman's argument in favor of remanding without vacating appears to have won the day, at least to the extent that the continuing trend in favor of remanding without vacating can be interpreted as evidence of his triumph.

As evidence of the continuing trend in favor of remanding without vacating, consider the words of a recent commentator who noted that "[t]ypically, the D.C. Circuit remands without vacating when the court believes that the agency action is consistent with the statute, but requires a more careful explanation." ${ }^{\text {11 }}$

${ }_{78}$ Id. at 466 (Randolph, J.).

78 See id. at 467 . Judge Randolph stated that "[r]emanding without vacating, as Judge Silberman advocates, not only violates the Administrative Procedure Act but also forces petitioners to serve out their suspensions while the Commission ponders its unlawful order." Id. at 467 . He concluded that " $[t]$ he remand-only disposition, embraced by Judge Silberman, is contrary to law. It rests on thin air." Id. at 490 Judge Silberman rejoined that "Judge Randolph would go one step further and vacate.... All arbitrary and capricious activity must be 'set aside' .... This assertion finds support in neither logic nor precedent; as far as I can determine, it is an argument that has never been presented by any party in any case - save one." Id. at 462.

7923 F.3d at 462-66. Part V of Judge Silberman's opinion is devoted to defending the remand without vacating disposition. Id. Judge Silberman's opinion concludes with an Appendix consisting of a table of D.C. Circuit cases "remanding for inadequate explanation without vacating the agency action." Id. at 466 (listing twenty-nine cases).

${ }^{80}$ Id. at 490-93. Part VI of Judge Randolph's opinion, titled "Remanding Without Vacating Violates the Administrative Procedure Act," is devoted to attacking the remand without vacating disposition. Id.

81 Craig N. Oren, Run Over By American Trucking Part I: Can EPA Revive its Air Quality Standards?, 29 ENVTL. L. REP. 10653 (1999) (emphasis added). For examples of remanding without vacating agency action in the wake of Checkosky, see Davis County Solid Waste Mgmt. v. EPA, 108 F.3d 1454, 1460 (D.C. Cir. 1997) (remanding but not vacating across the board, instead limiting vacation to rules as applied to small businesses); A.L. Pharma, Inc. v. Shalala, 62 F.3d 1484, 1492 (D.C. Cir. 1995) (remanding without vacating FDA order despite the fact that "[ $t]$ he FDA had made no attempt to "cogently explain" why challenges to its order were mistaken) (internal citation omitted); Idaho Farm Bureau Fed' $n$ v. Babbitt, 58 F.3d 1392, 1405-06 (9th Cir. 1995) (remanding without vacating Fish and Wildlife Service's regulation, despite "significant procedural error" in the form of noncompliance with APA mandated notice and comment procedure); American Med. Ass'n v. Reno, 57 F.3d 1129, 1135 (D.C. Cir. 1995) (remanding without vacating DEA regulations despite the agency's failure to provide adequate reasons for its action); But see Clean Air Implementation Project v. EPA, No. 96-1224, 1996 WL 393118, at*1 (D.C. Cir.) (per curiam) (granting motion for vacation and remand despite EPA's request for remand without 


\section{The Massive Potential Scope of Remanding Without Vacating}

Regardless of current trends in the courts, the remand without vacating disposition is worthy of further scrutiny because of its potentially broad scope. "The vast majority of agency rules that are held to be invalid under the arbitrary and capricious standard are likely to qualify for remand without vacation through application of the test announced in Allied-Signal." 82

The test announced in International Union ${ }^{83}$ and applied in Massachusetts $v . N R C,{ }^{84}$ Allied-Signal, ${ }^{85}$ ICORE $^{86}$ and other cases, considers two factors when deciding whether remanding without vacating is proper: "The seriousness of the order's deficiencies ... and the disruptive consequences of an interim change . .." ${ }^{17}$ When considering the seriousness of the order's deficiencies, a court can almost always find that, even though the agency has failed to consider $X$ alternative or $Y$ disadvantage, "there is at least a serious possibility that the agency will be able to substantiate its decision on remand." 88

Consider the court's reasoning in Allied-Signal. ${ }^{89}$ In refusing to vacate an NRC cost recovery rule, the court, quoting International Union, recited the two relevant factors ${ }^{90}$ for deciding whether remanding without vacating is proper. The court noted that "[i]t is conceivable that the Commission may be able to explain how the principles supporting an exemption for educational institutions do not justify a similar exemption for domestic $U_{6}$ converters. $^{\text {"11 }}$ Later in the opinion, the court noted "the possibility that the Commission may be able to justify the Rule" as sufficient to jump the first hurdle required to

\footnotetext{
vacation).

${ }_{82}$ Pierce, supra note 7, at 75-76.

${ }^{83} 920$ F.2d 960, 967 (D.C. Cir. 1990).

84924 F.2d 311, 336 (D.C. Cir. 1991).

85988 F.2d 146, 150-51 (D.C. Cir. 1993).

86985 F.2d 1075, 1081-82 (D.C. Cir. 1993).

87 Int'l Union, 920 F.2d at 967. See supra Part I.B.1. (discussing International Union and its progeny).

88 Allied-Signal, Inc. v. NRC, 988 F.2d 146, 151 (D.C. Cir. 1993). Pierce makes this point in Pierce, supra note 7, at 75-76. But see Chemical Mfrs. Ass'n v. EPA, 28 F.3d 1259, 1268 (D.C. Cir. 1994), in which the D.C. Circuit vacated the EPA's decision to list a particular substance as a "high risk air pollutant" holding that "[n]o remand for further administrative proceedings is warranted because the EPA did not suggest ... that there is any alternative basis in the record for including MDI on the high risk list."

8988 F.2d at 151.

90 Id. at 150-51 (quoting Int'l Union, 920 F.2d at 967).

91988 F.2d at 151 (emphasis added).
} 
abstain from vacation. ${ }^{92}$

It appears from this language that it is a simple task for a thoughtful court to imagine some nontrivial counterfactual scenario in which the agency's rule makes sense. For instance, in Allied-Signal, the court hypothesized that the NRC "may develop a reasoned explanation based on an alternative justification" and then ventured some guesses as to what such an alternative justification might look like. ${ }^{93}$ The point is not that the court was being intellectually dishonest, but rather that given the lax standard applied in these cases, a rigorous consideration of the myriad justifications for a given rule will often turn up explanations sufficient to create a "serious possibility" that an agency will be able to "substantiate its decision on remand." This is especially true when any "conceivable" explanation counts as evidence of a "serious possibility." 96

The second International Union factor-the disruptive consequences of an interim change-also fails to constrain courts' use of the remand without vacation disposition. A court considering the consequences of an interim change can almost always find that the consequences of vacating may be quite disruptive because, in light of Bowen v. Georgetown University Hospital, ${ }^{97}$ which holds that an apparently unlimited grant of rulemaking power does not include the power to issue rules with retroactive effect, ${ }^{98}$ virtually all vacations risk a regulatory gap between the period when the initial, unlawful regulation is set aside and the time when a second, lawful regulation takes its place. ${ }^{99}$ This regulatory gap, in most cases, will qualify as sufficiently disruptive to overcome the second hurdle to remanding without vacating. Considering the disruptive consequences of an interim change, the Allied-Signal court noted that vacation could be disruptive because it would require the NRC to refund collected fees. The court also weighed the Commission's inability to later collect the refunded fees under a new, lawful regulatory scheme (given Georgetown's presumption against retroactive rulemaking ${ }^{100}$ ) in evaluating the potential disruptive consequences of an interim change. ${ }^{101}$

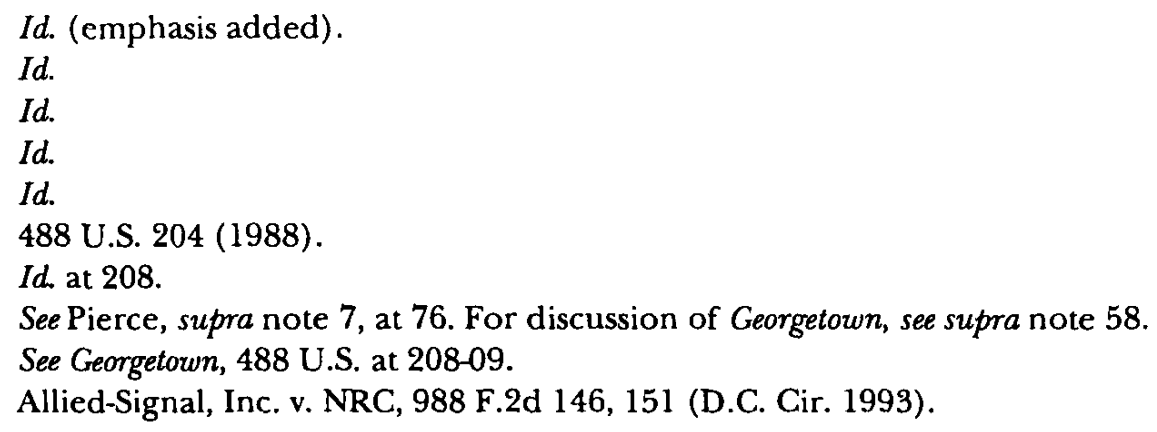


Having described the current trend toward increased use of remanding without vacating and explained the potentially broad scope of the current doctrine "cabining" the remand without vacation disposition, Part II now discusses the policy rationales both in favor of and against the disposition.

\section{POLICY RATIONALES}

This Part addresses the argument that the pragmatic need for remanding without vacating is so overwhelming as to render moot the legal arguments against the procedure. The discussion concludes that the practical benefits of remanding without vacating are not so powerful as to justify disregarding the legal case against the procedure. The punch-line is defensive: the policy arguments are crosscutting and whether the world is a better place without mandatory vacation is unclear at best.

The APA was enacted in 1946 as a compromise measure between supporters of the New Deal and critics of the emerging administrative apparatus concerned about unconstrained administrative power. ${ }^{102}$ Although section 10 of the APA, dealing with judicial review, essentially codified judicial practice at the time the statute was enacted, the APA's arbitrary and capricious standard represents a modest victory for the proponents of judicial review of agency action. ${ }^{103}$ The APA's procedural checks and judicial oversight were seen as critical responses to the largest problem associated with the administrative state-agency discretion. ${ }^{104}$ Agencies exert substantial control over people's lives and wield what in many ways appears to be lawmaking power. Close adherence to the APA's requirements is a necessary part of the bargain ${ }^{105}$ because it is only through adherence to the APA (and the agencies' organic statutes) that agencies wield specifically delegated powers rather than unbridled and unconstitutional authority.

On this account the benefits of "deossification"-that is, the benefits of streamlining the regulatory process-cannot be weighed against the benefits of enforcing agencies' legal duty to engage in rea-

102 Stephen G. Breyer, et al., Administrattve Law and Regulatory Policy: ProbLEMS, TEXT, AND CASES 22 (4th ed. 1999).

${ }^{103} I d$ at 24.

104 Id.

105 See Vermont Yankee Nuclear Power Corp. v. Natural Resources Defense Council, 435 U.S. 519, 524 (1978) (holding that courts applying procedures not found in the APA or any other statute "totally disrupt the statutory scheme, through which Congress enacted 'a formula upon which opposing social and political forces have come to rest'"). 
soned decisionmaking. Professor Pierce's argument that "[s]ince I perceive greater benefits in deossifying the rulemaking process than in enforcing the duty to engage in reasoned decisionmaking, I am comfortable with the trade-off implicit in adoption of the remand without vacation remedy," herence to the APA's mandates is a crucial part of the legal balance that allows agencies to exert the power they do, the APA's requirements take on a constitutional, ${ }^{107}$ rather than a merely prudential, dimension.

The primary policy argument in favor of remanding without vacating is that the disposition allows courts to provide agencies a second chance. Because agencies tackle complex problems and because agency action can be challenged in many ways and from many directions, proponents argue that agencies should be permitted to present new evidence responding to challengers' attacks when it appears that the agency could likely do so and when the adverse consequences of vacation are likely to be significant. Judge Silberman presented a flavor of this argument in Checkosky when he held that courts should not have to decide whether an agency's action is "unlawful or lawful on ... first pass, even when the judges are unsure as to the answer because they are not confident that they have discerned the agency's full rationale." ${ }^{108}$ It is not clear, however, that remanding without vacating is a necessary procedure to save well-reasoned agency action that, for some reason, cannot be sustained "on first pass."

First, the party challenging agency action has the burden of proving that the agency action is arbitrary. In a world requiring vacation of arbitrary action, the fear that otherwise well-reasoned regulations will necessarily be vacated ignores the fact that there is not even a risk of vacation unless the challenger is at least able to present evidence sufficient to make a prima facie showing of arbitrariness. The burden of proof prevents the opening of the floodgates by ensuring that the bulk of well-reasoned regulations will not be vacated because the challenger will not be able to make a showing that the regulations are arbitrary. ${ }^{109}$ The set of well-reasoned regulations subject to vaca-

\footnotetext{
106 See Pierce, supra note 7, at 78.

107 At one extreme, see A.L.A. Schechter Poultry Corp. v. United States, 295 U.S. 495 (1935) (holding that because "the discretion of the President ... is virtually unfettered" the "authority thus conferred is an unconstitutional delegation of legislative power").

108 Checkosky v. SEC, 23 F.3d 452, 462 (D.C. Cir. 1994) (Silberman, J.).

109 To some extent, this argument turns on how difficult it is to surmount the burden of proving a regulation arbitrary. It might be argued that the legal standard for making a prima facie case of agency arbitrariness is too low, in which case re-
} 
tion, that might otherwise be saved by a remand without vacation, is limited to that set of regulations that are well-reasoned but cannot be successfully defended by the agency on first pass.

Second, those who point to the current pool of agency actions as evidence that, in the absence of a remand without vacating procedure, the agencies' duty to defend their regulations on first pass would be a Herculean task, fall prey to an ex-post fallacy by judging the effects of a rule requiring vacation against the backdrop of regulations enacted in response to a rule giving agencies a second chance. If many current regulations appear hard to defend, this is just as likely to be a consequence of the current rule (which encourages poor reasoning) as a function of agencies' inherently difficult duties. The availability of a remand without vacation disposition may give agencies an incentive to invest less of their scarce resources in ensuring that their regulations are well-reasoned. ${ }^{110}$ Remanding without vacating decreases the cost to the agency of acting arbitrarily because under a remand without vacating regime arbitrary agency action results in only having to patch up the holes in the faulty reasoning rather than requiring a restart from scratch. Because at least a portion of agency action will not be challenged, remanding without vacating gives agencies an incentive frequently to engage in insufficient reasoning, saving costs on the front-end, knowing that they will have to repay only a fraction of those costs when a portion of those regulations are sent back by the courts for another try. ${ }^{11}$ It is at least plausible that requiring vacation, rather than permitting agencies to repair

manding without vacating is a sensible counterweight to ensure that the "proper" number of regulations is passed. But this is an argument for requiring a more stringent burden of proof, not an argument for casting aside the APA's duty of reasoned decisionmaking. Two wrongs don't make a legal right. Furthermore, it is not clear that the burden of proof is improperly calibrated simply because it is easy to show that an agency has acted arbitrarily. Perhaps the simplicity of this showing, if it is indeed simple, reflects a democratic decision about the hurdles we want to erect before an agency can exert control over people's lives. Frequent complaints about overregulation, while not unambiguously legitimate, provide some support for this proposition.

110 The validity of this argument turns on a comparison between resources saved in the decisionmaking process and resources expended through increased litigation. That is, remanding without vacating encourages sloppy agency reasoning if the resources saved from shirking in the decision-making process outweigh the resources expended from defending the more legally vulnerable regulations from increased legal challenges.

T11 Even Professor Pierce, a defender of remanding without vacating, concedes that "[a]gencies will know in advance that a rule can remain in effect in its entirety in most cases even if the agency is held to have violated the duty to engage in reasoned decisionmaking. That knowledge will encourage agencies to devote less time and fewer resources to their efforts to comply with that duty." Pierce, supra note $\mathbf{7}$, at 78. 
their reasoning, would, in the aggregate, result in better reasoned agency actions.

An additional nuance to the incentives argument relies on regulated parties' likely response to a regime in which "relief" is often limited to remand without vacation. Professor Levin, a supporter of the current regime, recognizes that "judicial reluctance to disturb administrative actions even if they are poorly reasoned or procedurally defective could unduly reduce the public's incentive to challenge agency mistakes and perhaps would encourage agencies to do their work less carefully in the first instance."12 This intuition is confirmed by conversations with practitioners who voice the belief that it is often not in the client's interest to challenge a poorly reasoned regulation because, in many instances, the most that can be achieved is a remand without vacation which offers the regulated party little solace.

One response to the incentives argument, offered by Professor Sunstein, is that if "a system in which inadequately justified rules are invalidated would create more pressure to produce adequate justifications in the first instance, ${ }^{113}$ then the proper response is not an across-the-board rule requiring vacation in all cases." Rather, Sunstein argues that remanding without vacating should be restricted to "special circumstances" of the type delineated in International Union. ${ }^{114}$ Although this response addresses the incentives argument on its terms, it fails to grapple with the legal argument that, if the APA requires vacation, then even vacation limited to special circumstances is still in violation of the APA.

In addition, the argument that remanding without vacating can successfully be limited to circumstances where the cost of vacation is high and the likelihood of adequate justification the second time around is high, assumes that the judicial task is well suited to making this distinction. ${ }^{115}$ Courts, choosing between vacating and merely remanding to the agency, are faced with a difficult balancing actdetermining the likelihood of a successful agency defense the second time around and predicting the likely effects of vacation. ${ }^{116}$ Support-

\footnotetext{
112 Levin, supra note 3 at 5.

113 Cass R. Sunstein, Is the Clean Air Act Unconstitutional?, 98 MICH. L. REv. 303, 374 (1999).

114 Id.

115 Judicial uncertainty, rather than inaccuracy, is sufficient to address the argument that courts could successfully limit remanding without vacating to circumstances where it would be most useful.

116 Professor Levin recognizes this concern. He notes that "some observers mistrust the kind of open-ended balancing of equities that the remand without vacation practice entails. They suspect that it may lead the courts into making fundamentally
} 
ers of remanding without vacating are content to admit that the procedure requires judicial balancing. ${ }^{117}$ For instance, in Checkosky, Judge Silberman admits that the decision whether to vacate or remand without vacating requires a sort of open-ended judicial balancing:

In practice, the distinction-between a case where the reviewing court determines that the agency's explanation for its action is so crippled as to be unlawful and one where the court, unsure of the agency's reasoning, remands for a fuller explanation without expressing a view as to whether the agency's action is unlawful-is a matter of degree. ${ }^{118}$

Initially, the balancing test applied by Judge Silberman and endorsed by Professor Sunstein is tremendously open-ended. The vast majority of agency action is capable of some non-trivial defense and can reasonably be said to create problems if vacated. ${ }^{119}$ Given that the test leaves significant room for judicial discretion, the issue is whether this discretion can be intelligently exercised. A plausible answer is that it cannot. Requiring courts to engage in speculation regarding possible justifications for an apparently unreasoned actionessentially counter-factuals involving hypothetical arguments that the agency might have been able to make had it collected, reviewed, or presented some other data or had it considered some other alternatives or disadvantages to its chosen course of action-appears to strain the judicial capacity by requiring courts to look beyond the record before them and delve into an inquiry for which they are illequipped. ${ }^{120}$ The Supreme Court appears to agree with this general

administrative decisions that exceed judicial competence." Levin, supra note 3, at 5.

117 Judge Silberman readily concedes that remanding without vacating is a discretionary procedure to be used in some instances but not in others. In Checkosky, he held that when an agency has been unclear, "the proper course . . . is to remand so as to afford the agency an opportunity to set forth its view in a manner that would permit reasoned judicial review." 23 F.3d at 462 . He later stated, "[t]o be sure, there are cases where an agency's failure to state its reasoning or to adopt an intelligible decisional standard is so glaring that we can declare with confidence that the agency action was arbitrary and capricious." Id. at 463 . So, in practice, when an agency has failed properly to explain itself, sometimes the court should remand to the agency for further explanation and sometimes the court should hold unlawful and set aside the regulation. How difficult it is to decide between these two options becomes the critical, unanswered question.

118 Id. at 464.

119 See supra Part I.C.

120 One might respond that courts are not more poorly equipped to delve into this inquiry than they are to delve into any other APA-mandated inquiry. The answer is that the task of judicial review, limited to the record, see 5 U.S.C. $\$ 706$ (1994) (stating that "the court shall review the whole record or those parts of it cited by a party ...."), including the agency's statement of basis and purpose, see 5 U.S.C. $\$$ 553 (c) (1994), is different in kind from judicial review on the basis of what the court 
logic: "[I]f courts continually review agency proceedings to determine whether the agency employed procedures which were, in the court's opinion, perfectly tailored to reach what the court perceives to be the 'best' or 'correct' result, judicial review would be totally unpredictable."121

Another argument advanced to strengthen the case for remanding without vacating is that, post-Georgetown, vacation results in harmful regulatory gaps or vacuums because, during the period between vacation and reenactment of some other (or the same) rule, the regulated parties are left ungoverned. Before Georgetown, the traditional response was for agencies, in the wake of vacation, to regulate retroactively in order to cover the period of time between the initial vacation and reenactment of some alternative. The retroactive regulation solved the vacuum both literally, by regulating conduct in the past, and it created compliance incentives because regulated parties were on notice that deviations during the interim period would catch up with them once the retroactive regulation was instituted. "An agency's ability to issue an interim rule on remand became much less valuable after Georgetown because the vacate and remand remedy always creates a regulatory void between the putative effective date of the vacated rule and the effective date of the interim rule issued on remand." ${ }^{122}$ Therefore, "[t] he case for remands without vacation has become stronger in the wake of ... Georgetown..., which held that an agency cannot adopt a rule that applies retroactively to completed transactions unless Congress has explicitly conferred such authority." 123

The Georgetown argument, however, ignores that agencies have other options to minimize the disruptive consequences of vacation. For example, the agency may attempt to avoid regulatory gaps by issuing interim rules. ${ }^{124}$ Recent scholarship and case law supports the proposition that " $[c]$ ourts of appeals now appear prepared to allow

thinks the agency might have done or might be able to do. The former is an inquiry cabined by the record, the latter is a free-floating analysis of potentially difficult counter-factuals. This distinction is made clear in Vermont Yankee Nuclear Power Corp. v. Natural Resources Defense Council, 435 U.S. 519, 546 (1978) (holding that if the agency's action "is not sustainable on the administrative record made, then the ... decision must be vacated .... The court should engage in this kind of review and not stray beyond the judicial province to explore the procedural format or to impose upon the agency its own notion of which procedures are 'best.'”).

121 Vermont Yankee, 435 U.S. at 546.

122 Pierce, supra note 7, at 78.

123 Levin, supra note 3 , at 5.

124 See Shell Oil Co. v. EPA, 950 F.2d 741 (D.C. Cir. 1991); Mid-Tex Electric Coop. v. FERC, 822 F.2d 1123 (D.C. Cir. 1987). 
agencies to issue "interim rules." 125 In addition, agencies may issue rules without going through the burdensome notice and comment procedure if they show "good cause." 126 The "good cause" exception to the APA's notice and comment procedure is an example of how the APA explicitly deals with the need for agenicies to act quickly. The APA's explicit provision for cases in which agencies must act quickly might give rise to a presumption under the expressio unius canon of construction that other innovations (including remanding without vacating) designed to avoid regulatory vacuums should not be read into the text absent clear language. Finally, agencies may apply for a stay of a vacation order, again preventing the "nightmare" regulatory vacuum scenerio. "If the agency believes that vacating its order or rule would cause difficulties, it has the option of applying for a stay of the mandate, at which point it may make its arguments regarding irreparable harm and other considerations." 127

In sum, if the APA mandates vacation of arbitrary agency action then arguments that mandatory vacation is bad policy are alone insufficient. The APA's judicial oversight and procedural hurdles are part of an interbranch compromise the terms of which are matters of constitutional, not merely prudential, importance. The APA's compromise, permitting the executive to wield what appears to be legislative power cabined by judicial review and procedural checks, should not lightly be disrupted by extra-legal procedures. The argument that mandatory vacation would render the regulatory task impossible takes a pool of poorly reasoned agency action as a given when, in fact, it is equally likely that poorly reasoned regulations in the status quo are a product of the incentives created by the low cost of arbitrariness imposed by the current rule's option for a second chance. Second, the argument ignores several alternatives to a regulatory vacuum resulting from vacation. Finally, attempts to cabin remanding without vacating to instances in which the action is likely to be sustained on remand and the cost of vacation is high are likely to fail both because the standard is exceedingly vague and because the required balancing places an undue strain on judicial capacity.

\footnotetext{
125 Sunstein, supra note 113, at 372 (citing Chemical Mfrs. Ass'n v. EPA, 28 F.3d 1259, 1268 (D.C. Cir. 1994); Checkosky v. SEC, 23 F.3d 452, 462-66 (D.C. Cir. 1994) (per curiam); Mid-Tex, 822 F.2d at 1130-32).

1265 U.S.C. $\$ 553$ (b) (3) (1994) (stating that agencies must submit rules to notice and comment " $[\mathrm{e}] \mathrm{xcept}$... when the agency for good cause finds (and incorporates the finding and a brief statement of reasons therefor in the rules issued) that notice and public procedure thereon are impracticable, unnecessary, or contrary to the public interest").

127 Checkosky, 23 F.3d at 493 (Randolph, J.).
} 
Having at least established the possibility that we lack sufficient information to confidently say that remanding without vacation is good policy, and having established that we might be better off under a mandatory vacation regime, Part III considers the legal arguments on both sides of the remanding without vacating debate.

\section{LEGAL ARGUMENTS}

This Part presents the legal arguments on both sides of the remanding without vacating question and concludes that, although there are substantial arguments in both directions, the legal case against remanding without vacating is superior. Part III.A discusses the text of APA section 706 and concludes that the best reading of the text requires vacation. Part III.B then considers the legislative history and purpose of the APA in order to determine whether either source sheds light on the text. Part III.C discusses canons of construction that may seem to favor interpreting the APA to permit remanding without vacating, but ultimately finds these canons unpersuasive. Finally, Part III.D draws on judicial precedent, from both the Supreme Court and the lower courts, to demonstrate the illegality of remanding without vacating arbitrary agency action.

\section{A. The Text of the APA}

It is appropriate to begin the legal inquiry by examining the text of the APA. ${ }^{128}$ At first cut, the text of the APA appears to require courts-contrary to current practice-to vacate unlawful agency action. Section 706 of the APA states, in relevant part: "The reviewing court shall... hold unlawful and set aside agency action, findings, and conclusions found to be ... arbitrary, capricious, an abuse of discretion, or otherwise not in accordance with law." ${ }^{29}$ The text clearly

\footnotetext{
${ }^{128}$ Beginning with the text is uncontroversial and the Court has, with increasing vigor, endorsed the text as the starting point of statutory interpretation. See, e.g., Carter v. United States, 530 U.S. 255, 271 (2000) (holding that statutory interpretation "begin[s] with the text, not by 'psychoanalyzing those who enacted it") (quoting Bank One Chicago, N.A. v. Midwest Bank E' Trust Co., 516 U.S. 264, 279 (1996)) (Scalia, J. concurring in part and concurring in the judgment).

1295 U.S.C. $\$ 706(2)$ (A) (1994). Section 706 states, in full: Scope of review

To the extent necessary to decision and when presented, the reviewing court shall decide all relevant questions of law, interpret constitutional and statutory provisions, and determine the meaning or applicability of the terms of an agency action. The reviewing court shali-

(1) compel agency action unlawfully withheld or unreasonably delayed; and

(2) hold unlawful and set aside agency action, findings, and
} 
states that courts must "set aside" arbitrary agency action and this command ought to preclude courts from remanding arbitrary agency action without also setting aside such action.

One might argue that the "set aside" language of the APA is ambiguous-maybe "set aside" permits remanding without vacating. But the meaning of "set aside" is not nearly so open-ended. First, judicial practice confirms that the power to "set aside" regulations at least includes the power to vacate regulations. The fact that, in some cases under APA section 706, courts vacate arbitrary regulations "simply as a matter of course" 130 demonstrates that the definition of "set aside" includes vacation.

The remaining question is whether to "set aside" requires, or is exclusively synonymous with, vacating, thereby precluding courts from remanding without vacating. The definitions of both "set aside" and "vacate" preclude reading the term "set aside" to permit a disposition other than vacation-both words are defined in terms of each other and both exclude mere suspension or a stay of enforcement. ${ }^{131}$ Black's Law Dictionary defines "set aside" as "[t]o reverse, vacate, cancel, annul, or revoke a judgment, order, etc." ${ }^{132}$ Similarly, The Ameri-

conclusions found to be-

(A) arbitrary, capricious, an abuse of discretion, or otherwise not in accordance with law;

(B) contrary to constitutional right, power, privilege, or immunity;

(C) in excess of statutory jurisdiction, authority, or limitations, or short of statutory right;

(D) without observance of procedure required by law;

(E) unsupported by substantial evidence in a case subject to sections 556 and 557 of this title or otherwise reviewed on the record of an agency hearing provided by statute; or

(F) unwarranted by the facts to the extent that the facts are subject to trial de novo by the reviewing court.

In making the foregoing determinations, the court shall review the whole record or those parts of it cited by a party, and due account shall be taken of the rule of prejudicial error.

5 U.S.C. $\$ 706$ (1994).

130 Checkosky, 23 F.3d at 491 (Randolph, J.) (citing, e.g., Kooritzky v. Reich, 17 F.3d 1509, 1514 (D.C. Cir. 1994); American Petroleum Inst. v. EPA, 906 F.2d 729, 742 (D.C. Cir. 1990); Advanced Micro Devices v. CAB, 742 F.2d 1520, 1542-43, 1544 (D.C. Cir. 1984)).

131 "[T]he Court frequently uses the dictionary to provide meaning to key statutory terms." William N. ESKRIDGe, JR. AND PhILIP P. FRICKEY, CASES AND MATERIALS ON Legislation, Statutes, and the Creation of Public Policy 625 (2d ed. 1995); Note, Looking It Up: Dictionaries and Statutory Interpretation, 107 HARV. L. REV. 1437, 1438 (1994) (noting that dictionary definitions were used fourteen times more in the Supreme Court's 1992 Term than in the Court's 1981 Term).

132 Black's LAW Dictionary 955 (6th ed. 1991) (emphasis added). 
can Heritage Dictionary defines "set aside" as "1. To separate and reserve for a special purpose. 2. To discard or reject. 3. To declare invalid; annul or overrule: The court has set aside the conviction." 133 Black's then defines "vacate," in part, as "[t]o annul; to set aside, to cancel or rescind." 134 The definition explicitly states that, "[a]s applied to a judgment or decree [vacate] is not synonymous with 'suspend' which means to stay enforcement of judgment or decree." American Heritage defines "vacate," in the legal context, as "[ $\mathrm{t}] \mathrm{o}$ make void or annul." 136 Both the definition of "vacate" ("to set aside") and the definition of "set aside" (to "vacate") explicitly distinguish the act of setting aside (required by the text of the APA) from the act of merely suspending enforcement. It requires no definitional trickery to read the APA's "shall ... set aside" language as requiring courts to vacate arbitrary agency action. In short, "[s]etting aside means vacating; no other meaning is apparent." 137

The Supreme Court has also held that the term "'shall' ... creates an obligation impervious to judicial discretion." "138 Therefore, if

133 The American Heritage Dictionary of the English Language 1651 (3d ed. 1992). The definition of "set aside," quoted in the text, appears in the dictionary as a phrasal verb, listed under the definition of the word "set." Id. at 1650-51. A phrasal verb is a phrase consisting of a verb and an adverb or preposition "with a unitary meaning that cannot be deduced from the sum total of the meanings of its constituent parts." Id. at xl. While the first definition of "set aside" quoted in the text- "To separate and reserve for a special purpose"-may seem to help those arguing in favor of remanding without vacating, this definition appears to be referring to the setting aside of a physical object rather than the legal act of setting aside. It is instructive to note that the third definition-"To declare invalid; annul or overrule"-would seem to require vacation unless a court could somehow annul or invalidate a rule without vacating the rule. It is also helpful to note that this third definition, which cuts against remanding without vacating, is the definition of the term in the legal context; this is clear from the example following the third definition ("The court has set aside the conviction"). Note also that the third definition is consistent with the second, "discard or reject" definition as well.

I present evidence from both BLACK's and AMERICAN HERITAGE to attempt to allay concerns about "dictionary shopping." The definitions of "set aside" and "vacate" appear consistent across both dictionaries cited and a brief perusal of other dictionaries is likely to confirm these uncontroversial meanings. For a discussion of "dictionary shopping" and "definition shopping" (that is, the practice of searching out a dictionary or definition that supports the writer's predetermined reading of the text), see Note, 107 HaRv. L. REv. 1437, supra note 131, at 1447.

134 BLACK's LaW DictionaRY, supra note 132, at 1075.

135 Id.

136 AMERICAN HeRTTAGE DictionaRY, supra note 133, at 1969.

137 Checkosky v. SEC, 23 F.3d 452, 491 (D.C. Cir. 1994) (Randolph, J.).

138 Lexecon, Inc. v. Milberg Weiss, 523 U.S. 26, 35 (1998). See also Miller v. French, 530 U.S. 327,336 (2000) (holding that "the statutory command that such a motion shall operate as a stay during the [specified time] period indicates that the stay is mandatory") (internal quotations omitted) (alteration and emphasis in original). 
set aside means vacate, then courts have no choice but to vacate arbitrary agency action. A plausible argument then, is that the text of the APA creates no room for courts to abstain from vacation once they find an agency action arbitrary.

One possible escape route from the literal text of the APA is to argue that courts can find an agency action insufficiently reasoned, but not arbitrary, and thereby dodge the mandatory vacation requirement. Referring to the APA's text, one might argue that the agency action under consideration is not an "agency action ... found to be ... arbitrary, capricious, an abuse of discretion, or otherwise not in accordance with law." ${ }^{139}$ One might distinguish the regulation under review by arguing that the court lacks sufficient information to determine whether the regulation is arbitrary in the first place. ${ }^{140}$ Given that the court does not, and cannot, know whether the regulation is arbitrary, so the argument goes, remanding without vacating is not explicitly prohibited by the APA and is necessary in order for the court to conduct judicial review. The textual hook ${ }^{141}$ is that insufficiently reasoned agency action, remanded to the agency but not vacated, is not agency action that has been "found to be ... arbitrary." 142 On this account, the APA's use of the passive voice, requiring courts to set aside agency action found to be arbitrary, does not speak to timing. It does not say that courts must determine whether an agency action is arbitrary on first pass. Instead, the text merely states what courts shall do when they finally do determine whether an agency has acted arbitrarily. Because the text contains no provision triggering a finding of arbitrariness, courts may defer this decision and, as an interlocutory matter, remand without vacating in the process leading up to a decision on the arbitrariness question. For instance, in Checkosky, Judge Silberman held that the court could not determine whether the agency had been arbitrary and capricious without the benefit of further information from the agency. ${ }^{143}$ In this case, the remand was justified not because the agency had been arbi-

\footnotetext{
1395 U.S.C. $\$ 706(2)$ (A) (1994) (emphasis added).

140 This distinction, between arbitrary agency action and agency action insufficiently reasoned so as to prevent judicial review, is at the heart of the SilbermanRandolph debate in Checkosky. The Randolph line of reasoning, favored by this Article, holds that an agency's failure to provide sufficient explanation is, in itself, arbitrary. See Checkosky, 23 F.3d at 491 (Randolph, J.). In contrast, the (not unreasonable) Silberman view is that in some cases, an agency's failure to explain itself may block effective judicial review and hence make impossible the immediate resolution of whether the action is arbitrary. See id. at 454, 462-63 (Silberman, J.).

141 Many thanks to Michael Edney for the following insight.

142 5 U.S.C. $\$ 706(2)(\mathrm{A})$.

143 See Checkosky, 23 F.3d at 461.
} 
trary but rather because the court could not determine whether the agency's action had been arbitrary.

The response to this argument is two-fold. First, the distinction-between arbitrary action and insufficiently reasoned but possibly not arbitrary action-fails to account for all of the cases in which courts remand without vacating. There are some instances in which the court concedes that the agency has acted arbitrarily but nevertheless proceeds to remand the regulation without vacating. ${ }^{144}$ In these cases, where a court has found arbitrariness, Judge Silberman's distinction between arbitrary regulations and regulations the arbitrariness of which cannot be determined does not even come into play. The observation that a regulation, so lacking in explanation that a court cannot even determine whether or not it is arbitrary, need not be vacated under the APA, fails to rationalize instances in which courts remand without vacating regulations that the court finds arbitrary as they stand, but potentially redeemable. ${ }^{145}$ Furthermore, it does not explain remanding without vacảting in the case of regulations with notice and comment defects. ${ }^{146}$

Although on Judge Silberman's disposition of the case this issue-whether courts may remand without vacating concededly arbitrary agency action under section 706-was not reached in Checkosky, it remains an important question. How important is a different story. If courts are prohibited from remanding without vacating admittedly arbitrary action, but may refuse to vacate insufficiently reasoned agency action when the arbitrariness of the action is not yet clear, then this argument may only be a semantic victory. Courts that had previously abstained from vacating agency action that they had held arbitrary could simply recharacterize the agency action as insufficiently reasoned to determine arbitrariness and then remand to the agency to collect more information.

144 See, e.g., Transcanada Pipeline Ltd. v. FERC, 24 F.3d 305, 310 (D.C. Cir. 1994) (remanding without vacating a FERC order requiring plaintiff to recover costs through an incremental rate rather than a rolled-in rate despite holding that the Commission "crossed the line from the tolerably terse to the intolerably mute" and that "[t]oo much is lacking that a reasoned explanation would have supplied") (citations omitted); see also Allied-Signal v. NRC, 988 F.2d 146, 150 (D.C. Cir. 1993) (holding that "the Commission's denial of relief ... cannot be viewed as reasonable decision-making," but stating that "[a]n inadequately supported rule [] need not necessarily be vacated") (discussed supra at notes 59-66 and accompanying text).

145 See supra note 144.

146 For an argument along these lines, see Levin, supra note 3, at 4 (arguing that the Silberman justification for remanding to determine whether the regulation is arbitrary in the first place does not explain all of the cases in which remand without vacating is used). 
Even in those instances in which a court holds that it lacks sufficient information to determine whether an agency has regulated arbitrarily, the argument that courts may refrain from vacating is not particularly compelling. To say that a reviewing court is unable to determine whether an agency has acted arbitrarily because the agency has provided such an impoverished rationale for its action seems incoherent. The distinction, between cases in which the agency has behaved arbitrarily and cases in which the agency has not provided sufficient reasons for the court to determine whether or not the agency has behaved arbitrarily, seems to fly in the face of doctrine regarding the meaning of "arbitrary and capricious." "It is firmly settled that if a court must 'guess as to what the [agency's] decisional criteria are or should be,' the agency's order is arbitrary and capricious." 147 It seems preferable to characterize agency action that lacks sufficient justification as arbitrary. In Checkosky, Judge Randolph explained that "[d]ozens of [the D.C. Circuit's] opinions have stated this fundamental proposition of administrative law." ${ }^{148}$ Likewise, the court in Public Citizen, Inc. v. FAA noted that " $[\mathrm{t}]$ he requirement that agency action not be arbitrary or capricious includes a requirement that the agency adequately explain its result." 149

A final argument advanced in order to rebut the mandatory view of section 706 is that the rule of prejudicial error, recognized in the final clause of section 706, demonstrates that "shall . . set aside" cannot really mean "shall" set aside. ${ }^{150}$ The last clause of section 706 states: "In making the foregoing determinations, the court shall review the whole record or those parts of it cited by a party, and due account shall be taken of the rule of prejudicial error." "In1 light of this

${ }^{147}$ Checkosky v. SEC, 23 F.3d 452, 491 (D.C. Cir. 1994) (quoting Airmark Corp. v. FAA, 758 F.2d 685, 695 (D.C. Cir. 1985)).

148 Checkosky, 23 F.3d at 491. Judge Randolph listed a host of D.C. Circuit cases standing for the proposition that an agency has been arbitrary and capricious when it fails to explain adequately its action. See, e.g., Petroleum Communications, Inc. v. FCC, 22 F.3d 1164, 1172 (D.C. Cir. 1994) (holding that an agency action is arbitrary "[w] here the agency has failed to provide a reasoned explanation"); Horsehead Resource Dev. Co. v. Browner, 16 F.3d 1246, 1269 (D.C. Cir. 1994) (holding that an "agency must... articulate a satisfactory explanation" to avoid acting arbitrarily); Pontchartrain Broadcasting Co. v. FCC, 15 F.3d 183, 185 (D.C. Cir. 1994) (noting that "an unexplained departure from Commission precedent would have to be overturned as arbitrary"); American Tel. \& Tel. Co. v. FCC, 974 F.2d 1351, 1354 (D.C. Cir. 1992) (holding that an agency must "articulate a satisfactory explanation for its action"). In Checkosky, Judge Randolph listed at least five other cases supporting the proposition. 23 F.3d at 491 n.33.

149988 F.2d 186, 197 (D.C. Cir. 1993).

150 For an illustration of this argument, see ABA, supra note 6, at 4.

151 5 U.S.C. $§ 706$ (1994). 
language, the ABA points out that "shall" "must mean 'shall generally,' not 'shall always."'152 Since section 706 requires courts to implement a harmless error principle it could not possibly require courts to vacate all arbitrary agency action. ${ }^{153}$

The response to this argument is more persuasive. ${ }^{154}$ The language of section 706, mandating that "due account shall be taken of the rule of prejudicial error" ${ }^{\prime 155}$ can just as easily be read along side mandatory "shall" vacate language without making nonsense of the text. The APA states that " $[t]$ he reviewing court shall ... hold unlawful and set aside agency action... found to be ... arbitrary" and, "[i]n making the foregoing determinations ... due account shall be taken of the rule of prejudicial error." 156 The conclusion urged by the $\mathrm{ABA}$, that "shall" actually means "may," does not follow from the premise that the rule of prejudicial error is accounted for in the text of section 706. In fact, the harmless error exception to the "shall ... vacate" language gives rise to a strong inference that the term "shall ... vacate" is otherwise mandatory. If "shall vacate" did not require vacation, then the harmless error exception would be wholly unnecessary. The existence of explicit text qualifying the mandatory "shall" should lead us to believe that there are not other, implicit exceptions allowing the court to refrain from vacating for other reasons, such as the policy concerns articulated in International Union. ${ }^{157}$ In Tennessee Valley Authority v. Hill, ${ }^{158}$ the Supreme Court offered a similar argument in an analogous circumstance. ${ }^{159}$ In that case, the

152 ABA, supra note 6, at 4.

153 A related argument might be that remanding without vacating is a way of taking into account, or operationalizing, the prejudicial error rule. This argument, however, does little to support the practice of remanding without vacating concededly arbitrary action. Similarly, in cases of insufficiently reasoned but questionably arbitrary action, this argument fails to address this Article's claim that such action is either arbitrary because it is insufficiently reasoned or not arbitrary, and thus beyond the APA's reach, because the error is insignificant.

154 I do not take issue with the argument that courts should consider the whole act for guidance concerning the meaning of particular words or phrases within the act. See Kokoszka v. Belford, 417 U.S. 642, 650 (1974) (holding that "[w]hen 'interpreting a statute, the court will not look merely to a particular clause in which general words may be used, but will take in connection with it the whole statute"). For criticism of the whole act rule see RICHARd POSNER, The Federal COURTS: Crisis AND REFORM 281 (1985) (arguing that the whole act rule improperly assumes that statutes are written as a whole as opposed to being "product[s] of compromise").

1555 U.S.C. $\$ 706(1994)$.

156 Id.

157 The policy concerns are outlined in International Union, 920 F.2d at 967, and discussed supra in the text accompanying notes 44-45.

158437 U.S. 153 (1978).

159 See id. at 188 . 
Court held that certain exceptions to the otherwise mandatory text of the Endangered Species Act were evidence demonstrating the nonexistence of other, implicit exceptions: ${ }^{160}$ "In passing the Endangered Species Act of 1973, Congress ... create[d] a number of limited 'hardship exceptions.' ... [U]nder the maxim expressio unius exclusio alterius, we must presume that these were the only 'hardship cases' Congress intended to exempt."161

In conclusion, the text of the APA appears to prohibit courts from remanding without vacating arbitrary agency action. The requirement that courts "shall ... set aside" arbitrary action leaves little room for a disposition that accomplishes just the opposite by remanding arbitrary agency action while explicitly refusing to set aside such action. Although the plain text of the APA does not appear to sweep up agency action not "found to be"162 arbitrary, this distinction does little to rectify the currently widespread practice of remanding without vacating. First, the distinction is irrelevant to the class of cases in which courts remand without vacating concededly arbitrary action. ${ }^{163}$ Second, this Article concludes that courts should hold that when agency action is so lacking in reason that arbitrariness cannot be determined, such a lack of reasoning is necessarily arbitrary in itself.

\section{B. Legislative History and Purpose of the APA}

\section{Congressional Silence}

Another argument in support of remanding without vacating is that the apparently mandatory text of the APA should be discounted because "the legislative background of the APA contains little if any indication that Congress ever paid attention to the precise implications of the 'shall ... set aside' language of the Act." ${ }^{164}$ On this view, to interpret "shall ... set aside" to mandate vacation of arbitrary action is to take the language out of context and apply it to preclude a practice that Congress never meant to prevent. This Part addresses the argument that congressional silence should be taken as evidence

\footnotetext{
160 See id.

161 Id.

1625 U.S.C. $\$ 706$ (1994).

163 See supra note 144 (citing cases remanding without vacating concededly arbitrary agency action).

164 ABA, supra note 6, at 5 (citing ATtORNEy GeNERAL's MANUAL ON THE APA 108 (1947)). Professor Levin echoes this argument: "if one looks beyond the APA's language to its legislative background" it appears that Congress did not consider the implications of the mandatory "shall ... set aside" language in the APA. Levin, supra note 3 , at 5 .
} 
that the "literal" meaning of "shall . . set aside" cannot reasonably be taken as the correct meaning.

The argument against the mandatory reading of section 706 is buttressed by a second claim-addressed in Part III.C below-that when enacting the APA, Congress "was merely "restat[ing] the present law as to the scope of judicial review"165 and Hecht $v$. Bowles, ${ }^{66}$ a case supporting a presumption against curbs on courts' remedial discretion, was part of this law. In other words, members of Congress enacting the APA did so against a background presumption disfavoring encroachments on courts' broad remedial discretion: "Part of the 'present law' at that time was the Hecht case itself, which was handed down while the APA was being drafted. Some of the authors of the Act must have been aware of it."

There are several responses to the argument in favor of discounting the mandatory text of the APA in light of the enacting Congress's intent. First, the Supreme Court's increasing hostility to legislative history ${ }^{168}$ supports excluding the legislative history as a source of interpretive guidance. Unless congressional silence is more probative, or the text is significantly more ambiguous than this Article concludes it is, we should eschew relying on silence in the legislative history.

Second, even if legislative history is an appropriate guide in this instance, to argue that the seemingly mandatory text of the APA should be read as a mere suggestion simply because "the legislative background of the APA contains little if any indication that Congress

165 ABA, supra note 6 , at 5 (alteration in original), quoting ATTORNEY GeNERAL's MANuAl ON The APA at 108. But see Wong Yang Sung v. McGrath, 339 U.S. 33, 37 (1950) (noting that the APA was "a new, basic and comprehensive regulation of procedures in many agencies" and that it settled "long-continued and hard-fought contentions, and enacts a formula upon which opposing social and political forces have come to rest").

166321 U.S. 321 (1944).

167 ABA, supra note 6 , at 5.

168 Since Justice Scalia's appointment to the Court in 1986, the Court has increasingly rejected resorting to legislative history when confronted with a statute which is unambiguous on its face. See ESKRIDGE \& FRICKEY, supra note 131, at 624 (also noting that " $[t]$ he Court's opinions ... have tended to be more dogmatic about whether there is any ambiguity in statutes"); WILLIAM ESKRIDGE, JR., DYNAMIC STATUTORY INTERPRETATION ch. 7 (1994); Thomas Merrill, Textualism and the Future of the Cheoron Doctrine, 72 WASH. U. L.Q. 351, 365 (1994) (documenting the Court's increasing reluctance to refer to legislative history). For earlier support for the proposition that unambiguous text often precludes resort to legislative history, see, e.g., Tennesee Valley Authority v. Hill, 437 U.S. 153, 185 n.29 (1978) ("When confronted with a statute which is plain and unambiguous on its face, we ordinarily do not look to legislative history as a guide to its meaning."); see also Ex Parte Collett, 337 U.S. 55, 61 (1949) (collecting cases). 
ever paid attention to the precise implications of the 'shall... set aside' language" 169 seems like a clear case of using legislative history in a way that conjures up the late Judge Leventhal's description of citing legislative history as "akin to "looking over a crowd and picking out your friends." $" 170$

That the legislative history is silent on the meaning of "shall ... set aside" is potentially consistent with two hypotheses: (1) Congress was aware of the important policy in favor of upholding courts' remedial discretion and, by remaining silent in light of text that might appear to contravene this discretion, we can presume that Congress did not intend "shall" to limit the discretion of judges to impose a broad range of remedies; or (2) Congress intended a targeted intrusion on courts' remedial discretion by requiring that courts vacate agency action upon a finding that such action is arbitrary, congressional silence is merely evidence that there was little debate or confusion surrounding the clearly mandatory "shall ... set aside" language.

In favor of the first hypothesis is Justice Stevens's "dog didn't bark" canon. ${ }^{171}$ Because no speaker in the legislative history of the APA stated that an important presumption was being overturned, we should presume that no challenge to the presumption was intended.

On the other hand, there are several other inferences that may properly be drawn from silence in the contemporary legislative history. Hypothesis two above is just one example. It is controversial at best to claim the fact that the "dog didn't bark" settles the matter. In favor of attributing no meaning at all to legislative silence is the fact that the true meaning of such silence is inherently speculative ${ }^{172}$ and lacks any formal legal significance. ${ }^{173}$

In addition to the cross-cutting conclusions that may be drawn from the APA's contemporary legislative history, there are crosscutting inferences that may be drawn from the legislative silence following the APA's enactment. One such inference, in favor of mandatory vacation, is that after enacting the APA, Congress was aware of judicial interpretation of the Act as requiring vacation and Congress's failure to amend the APA given this several-decades-old interpreta-

\footnotetext{
169 ABA, supra note 6, at 5.

170 Patricia Wald, Some Observations on the Use of Legislative History in the $1981 \mathrm{Su}$ preme Court Term, 68 IowA L. REv. 195, 214 (1983) (attributing the "picking out your friends" quote to Judge Harold Leventhal).

171 See Chisom v. Roemer, 501 U.S. 380, 396 n.23 (1991).

172 See John Grabow, Congressional Silence and the Search for Legislative Intent: A Venture into "Speculative Unrealities," 64 B.U. L. REV. 737 (1984).

173 See Johnson v. Transp. Agency, 480 U.S. 616, 672 (1987) (Scalia, J. dissenting) (stating that "vindication by congressional inaction is a canard").
} 
tion of the Act is evidence that Congress acquiesced to an interpretation of "shall ... set aside" as mandatory. ${ }^{174}$ Then again, the recent trend in favor of remanding without vacating, and Congress's silence (in the form of a failure to amend the APA) can again be taken as acquiescence, this time to the practice of remanding without vacating.

In light of the divergent inferences that may be drawn from the silence of both contemporary and subsequent Congresses, it is unclear whether such silence adds anything to the debate. This is especially true in light of the Court's more recent aversion to reliance on acquiescence and congressional silence as evidence of intent. ${ }^{175}$ Furthermore, as discussed below, ${ }^{176}$ Hecht is an important premise of the legislative intent argument because absent Hecht's presumption against curtailing courts' remedial discretion it is quite difficult to say anything definitive or useful about the meaning of congressional silence. Therefore, if the reading of Hecht is inaccurate then the legislative intent argument falters. Whether members of Congress enacting the APA did so against a background presumption that disfavored contravening courts' broad remedial discretion is unclear. What is clear is that the existence of a presumption against curtailing courts' remedial discretion at the time the APA was enacted is not prima facie evidence that Congress could not have intended the APA to require vacation by use of the words "shall . . set aside." The assumption that Congress, in whole or in part, was necessarily aware of the presumption against curtailing courts' remedial discretion and that Congress necessarily acted on the basis of this presumption rests on somewhat extravagant inferences about the legislative process. ${ }^{177}$

\section{A Common-Law Statute?}

Another argument in favor of deviating from the apparently mandatory text of the APA is that the APA is similar to the Sherman Act in the sense that it was meant to evolve over time. The ABA argues that

$\S 706$ as a whole is a classic example of a statute that Congress has adopted with the expectation that courts will flesh out its meaning

174 See, e.g., Johnson, 480 U.S. 616 (implementing the acquiescence doctrine to support the Court's prior interpretation of a statute); Flood v. Kuhn, 407 U.S. 258 (1972) (same).

175 See, e.g., Patterson v. McLean Credit Union, 491 U.S. 164 (1989) (rejecting the dissent's reliance on legislative inaction).

176 See discussion in Part III.C.

177 See Richard Posner, Statutory Interpretation-In the Classroom and in the Courtroom, 50 U. CHI. L. REV. 800, 806-07 (1983) (attacking the canons of construction as inconsistent with the realities of the legislative process). 
over time. The provision contains open-ended phrases such as "arbitrary and capricious," "substantial evidence," and "unreasonably delayed," which plainly call for judicial construction and adaptation to a broad variety of factual circumstances. One would not expect so broadly worded an enabling statute to impose severe constraints on the court's remedial discretion. ${ }^{178}$

A similar argument analogizes to the judicial power the APA grants over stays of agency action pending adjudication. "[I]n the APA itself Congress has given reviewing courts ... broad leeway to decide whether or not to stay administrative actions pending adjudication. 5 U.S.C. $\$ 705 . " 179$

Even if the APA was meant to be fleshed out, and even if some phrases in the APA seem open-ended, a powerful response to the ABA's argument is that the "shall ... set aside" command of the APA is not as ambiguous. It is highly unlikely that when a statute contains some ambiguous terms, all terms in the statute, including those with a more clear meaning, are meant to be interpreted as if they were undisciplined by the text.

In the APA context, although the meaning of "substantial evidence" may be unclear, the meaning of "shall . . . set aside" does not suffer from equal ambiguity. The open-endedness of a term such as "unreasonably delayed" does not provide courts with a license to interpret "shall ... set aside" as if it were equally ambiguous. If anything, the open-ended language located elsewhere in the APA serves as an informative counter example supporting the claim that some statutory provisions leave room for judicial elaboration while others intentionally create less space for creativity. For instance, the fact that section 705 of the APA gives courts "broad leeway to decide whether or not to stay administrative actions pending adjudication"180 is strong evidence that Congress was well aware of how to phrase statutory language to permit broad judicial discretion-perhaps Congress simply failed to grant courts such broad discretion in section 706 .

3. The Appellate Review Analogy

Finally, those arguing in support of the legality of remanding without vacating liken the practice of judicial review of agency action to appellate court review of lower federal court judgments, where appellate courts have significant discretion in fashioning remedies.

\footnotetext{
178 ABA, supra note 6, at 4.

179 Id.; see also Levin, supra note 3, at 4 (citing 5 U.S.C. $\$ 705$ (1994) and making the same argument quoted in the text).

180 ABA, supra note 6 , at 4.
} 
Reasoning by analogy, some argue that the appellate review model of judicial review casts doubt on a constraining reading of APA section 706(2) (A): "Related provisions cast further doubt on the literal reading of $\S 706$. Congress has essentially given appellate courts a free hand to fashion appropriate remedies when they review the decisions of lower courts."

In some contexts, Congress has granted the courts broad discretion. This does not mean, however, that Congress always grants the courts such broad discretion. The premise that appellate courts have broad remedial discretion when reviewing decisions of lower federal courts does not lead to the conclusion that courts have similarly broad discretion when reviewing agency action under section 706 . Indeed, it stands to reason that Congress might provide courts with broad discretion to fashion remedies when reviewing the highly variable category of lower court judgments and that Congress might also provide courts with little discretion when faced with insufficiently reasoned agency action, a confined and clearly identified subset of cases. In addition, given agencies' anomalous role in the separation of powers, ${ }^{182}$ judicial review might be more strict or disciplined when courts are reviewing agency action than when they are reviewing the judgments of other, constitutionally equal courts.

\section{Canons and Presumptions}

Those opposing the mandatory interpretation of section 706 argue that the text should be interpreted in light of a presumption against congressional limitations on courts' remedial power. In other words, in legislating that courts "shall ... set aside" arbitrary agency action, Congress must have meant that courts "may" set aside arbitrary agency action. Without a clearer statement, Congress could not have intended to curb courts' broad remedial discretion by requiring vacation. Consider the argument, as advanced by the ABA's Section of Administrative Law and Regulatory Practice and Business Law in a 1997 Report to the House of Delegates:

The literal interpretation of the "shall ... set aside" language of $\S$ 706 should be rejected. The statute should not be construed in isolation, but rather in light of a longstanding judicial presumption that counsels against a finding that Congress has placed curbs on the Courts' remedial discretion. The leading case of Hecht $v$. Bowles rejected an interpretation of price control legislation that would have compelled district courts to issue an injunc-

181 Id. (citing 28 U.S.C. $\$ 2106$ (1994)).

182 See discussion supra in Part II. 
tion whenever they found a violation of the law. The Court asserted that "equity practice with a background of several hundred years of history" militated in favor of a more flexible judicial role; only an "unequivocal statement of [legislative] purpose" would suffice to establish that Congress had meant to override that tradition. ${ }^{183}$

Other prominent legal scholars have spoken up in favor of the inherent powers rebuttal to the mandatory reading of section 706 . Even before the ABA report in favor of remanding without vacating, Judge Wald argued that "there are inherent powers in a reviewing court to postpone vacation until the agency has a chance to make things right." ${ }^{184}$ Similarly, Professor Levin noted that "[a] contrary reading [of section 706] might rest upon the federal courts' entrenched tradition of broad equitable remedial discretion." 185 And citing Hecht, ${ }^{186}$ Professor Levin argued that "the courts have gone so far as to create a presumption against finding that Congress has placed curbs on their remedial discretion." ${ }^{187}$ The final prong of this argument is that Webster $v . D o e^{188}$ proves that the Hecht line of cases remains viable today in the APA context: "at least one modern Supreme Court case appears to assume that the equity tradition described in Hecht does remain viable in APA cases." 189

The ABA's argument rests on the presumption established by $H e c h t,{ }^{190}$ that only an "unequivocal statement of [legislative] purpose" is sufficient to overcome courts' broad remedial discretion. ${ }^{191} \mathrm{Hecht}^{192}$ overturned the holding by the Court of Appeals for the District of Columbia which had, itself, overturned the district court. ${ }^{193}$ The Supreme Court held, consistent with the district court's original judgment, that, under section 205(a) of the Emergency Price Control Act of $1942,{ }^{194}$ upon a showing that the defendant had engaged or was about to engage in acts in violation of section 4 of the Act, the court

\footnotetext{
${ }^{183} \mathrm{ABA}$, supra note 6 , at 4 (internal citations omitted).

184 Wald, supra note 4, at 236.

185 Levin, supra note 3 , at 5 (citing 28 U.S.C. $\$ 2106$ ).

186321 U.S. 321 (1944).

187 Levin, supra note 3, at 4,5 (citing Hecht v. Bowles, 321 U.S. 321 (1943)). See also ESKRIDGE \& FRICKEY, supra note 131, at 654 (citing Hecht for the "[p]resumption that Congress will not withdraw the courts' traditional equitable discretion").

188486 U.S. 592, 604-05 (1988).

189 ABA, supra note 6, at 5 (citing Webster v. Doe, 486 U.S. 592, $604-05$ (1988)).

190321 U.S. 321 (1944).

191 Id. at $329-30$

192321 U.S. 321 (1944).

193 Id. at 331

194 56 Stat. 23, 50 U.S.C. $\$ 901$ (1942) (repealed 1946).
} 
was not required to grant an injunction. ${ }^{195}$ The Emergency Price Control Act stated, in relevant part, that "upon a showing by the Administrator that such person has engaged or is about to engage in any such acts or practices [in violation of section 4] a permanent or temporary injunction, restraining order, or other order shall be granted without bond." ${ }^{196}$ The Court held that "the Administrator, having established that a defendant has engaged in [such] acts" was not entitled to an injunction as a matter of right. ${ }^{197}$ The Court denied the Administrator's argument that the terms "shall be granted" required an injunction. ${ }^{198}$

The ABA report argues that "Hecht ... rejected an interpretation of price control legislation that would have compelled district courts to issue an injunction." 199 But Hecht is not nearly as helpful to those wishing to defend the legality of remanding without vacating at it first appears. First, Hecht does not stand for the proposition that mandatory "shall" language, directing the court to issue a particular remedy, may be interpreted as permissive. The Hecht Court reasoned that "[i]t seems apparent on the face of section 205(a) that there is some room for the exercise of discretion on the part of the court" ${ }^{200}$ because the Act explicitly stated that "a permanent or temporary injunction, restraining order, or other order shall be granted."201 The Court noted that

[i]t is indeed not difficult to imagine that in some situations [entering an order retaining the case on the docket in case violations recurred] might be the fairest course to follow.... Such an order, moreover, would seem to be a type of "other order" which a faithful reading of $\$ 205$ (a) would permit a court to issue. ${ }^{202}$

In other words, the Court held that the lower court was not required to issue an injunction, it was simply required to issue an injunction or other order. The Court did not hold that the use of the word shall in the Emergency Price Control Act did not saddle the lower court with compulsory duties, it only held that these duties were themselves flexible given the "other order" language of the Price Control Act. This argument is not available to defenders of remanding without va-

\footnotetext{
195 Hecht, 321 U.S. at 331.

196 Emergency Price Control Act of 1942 section 205(a), 56 Stat. 23, 50 U.S.C. §

901 (1942) (repealed 1946) (emphasis added).

197 Hecht, 321 U.S. at 322, 331.

198 Id. at 327-28.

199 ABA, supra note 6, at 4.

200321 U.S. at 328.

20150 U.S.C. $\$ 901$ (emphasis added).

202 Hecht, 321 U.S. at 328.
} 
cating. The APA states that " $[t]$ he reviewing court shall ... hold unlawful and set aside agency action, findings, and conclusions found to be ... arbitrary, capricious, an abuse of discretion, or otherwise not in accordance with law." ${ }^{203}$ Unlike the Emergency Price Control Act, the APA does not provide courts with the option of issuing some "other order." The only option is to "hold unlawful and set aside."

Second, the Emergency Price Control Act at issue in Hecht contained legislative history, not present in the APA context, disproving Congress's intent to limit courts' remedial discretion. The Hecht Court relied on the legislative history of the Price Control Act which made clear that "courts are given jurisdiction to issue whatever order to enforce compliance is proper in the circumstances of each particular case." ${ }^{205}$ It appears from this language that the court does indeed have discretion to issue the type of order it deems appropriate, but it is not at all clear that it has the authority to issue no order at all. The Hecht court makes the additional argument that the legislative history illustrating an intent to grant jurisdiction "hardly suggests an absolute duty" to issue orders "under any and all circumstances." 206 The relevance of the legislative intent to grant courts jurisdiction to issue orders in cases brought under the Price Control Act is not dispositive, however, of the question whether the Act not only grants jurisdiction but also requires the court to grant orders in particular circumstances.

Third, Hecht relied on principles of equity, not clearly relevant to the APA, to strengthen the presumption against curtailing courts' remedial discretion. The Hecht Court noted that "[w]e are dealing here with the requirements of equity practice with a background of several hundred years of history" and that "[ $t]$ he essence of equity jurisdiction has been the power... to mould each decree to the necessities of the particular case." ${ }^{207}$ This rationale, however, is specific to a presumption for judicial flexibility in the realm of equitable remedies and it does not necessarily apply to court decisions whether to vacate agency rules under the APA.

Fourth, the argument that the Hecht presumption requires reading the text of the APA as permissive misconstrues the weight of the Hecht canon. "Presumptions will generally not trump a contrary statu-

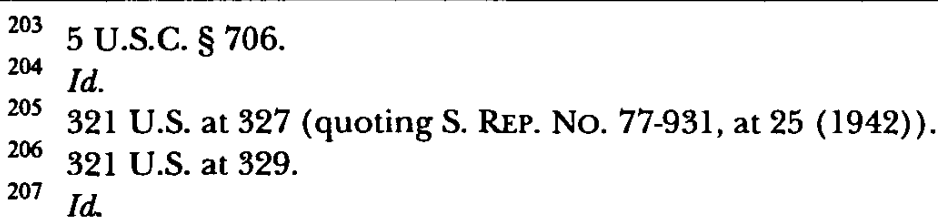


tory text." 208 The APA states that courts "shall ... set aside." ${ }^{209}$ Although "[a] presumption can be treated as a starting point for discussion, a tiebreaker at the end of discussion, or just a balancing factor,"210 recent Supreme Court precedent, holding that the presumption against curtailing courts' remedial discretion is overcome by mandatory "shall" language, should lead to skepticism of arguments giving significant weight to Hecht in the APA context. 211

Furthermore, Tennesee Valley Authority $v$. Hill ${ }^{212}$ supports a significantly more cabined approach to the Hecht canon. In Tennesee Valley Authority, the Court held that the Hecht canon may "take a court only so far." 113 The Court held that it is

the exclusive province of the Congress not only to formulate legislative policies and mandate programs and projects, but also to establish their relative priority for the Nation. Once Congress, exercising its delegated powers, has decided the order of priorities in a given area, it is for the Executive to administer the laws and for the courts to enforce them when enforcement is sought. ${ }^{214}$

The Court went on to explain that its function is not to shape remedies that arguably accord with common sense when the specific remedy to be issued is mandated by statute: "Our individual appraisal of the wisdom or unwisdom of a particular course consciously selected by the Congress is to be put aside in the process of interpreting a statute. Once the meaning of an enactment is discerned and its constitutionality determined, the judicial process comes to an end."215 Defenders of remanding without vacating, arguing that courts' equitable discretion allows them to refuse to vacate arbitrary agency action in the face of a statute enacted by Congress that says such action "shall" be vacated, ${ }^{216}$ side-step the separation of powers by favoring

208 ESKRIDGE \& FRICKEY, supra note 131, at 654 (citing Astoria Fed. Sav. \& Loan Ass'n v. Solimino, 501 U.S. 104 (1991)).

209 5 U.S.C. $\$ 706$ (1994).

210 ESKRIDGE \& FRICKEY, supra note 131, at 654.

211 See Miller v. French, 530 U.S. 327, 338 (2000) (holding that "although we should not construe a statute to displace courts' traditional equitable authority ... we are convinced that Congress' intent to remove such discretion is unmistakable in $\S 3626(\mathrm{e})(2)$," which states that a motion to terminate prospective relief "shall operate as a stay" of that relief).

212437 U.S. 153 (1978).

213 Id. at 194.

214 Id.

$215 I d$

216 Recall that “'shall' normally creates an obligation impervious to judicial discretion.” Lexecon, Inc. v. Milberg Weiss, 523 U.S. 26, 35 (1998); see also Miller v. French, 530 U.S. 327, 336 (2000) (holding that shall "indicates that the stay is mandatory"). 
remedies unanchored in the statutory text of the APA. ${ }^{217}$

In addition, the Hecht canon has significantly less weight in the context of statutes, such as the APA, prescribing secondary, as opposed to primary, rules. ${ }^{218}$ Often, the equitable discretion canon is invoked in the face of a statute regulating primary conduct. For instance, in Tennesse Valley Authority, ${ }^{29}$ the Hecht canon was advanced by one of the parties ${ }^{220}$ to argue that the Court was not obligated to grant an injunction in response to a violation of the provision of the Endangered Species Act requiring federal agencies to take actions necessary to ensure that their programs do not jeopardize endangered species. In this instance, the canon has comparatively more weight-a statute making certain conduct illegal should not be presumed to require courts to issue a particular form of remedy. In contrast, section 706 of the APA is a secondary rule-it speaks to the scope of courts' duty to enforce primary rules. In stating that courts "shall ... hold unlawful and set aside" certain agency action, section 706 tells courts what to do once they have found a violation of a primary rule-they are to set such action aside. In this context, where the APA specifically addresses remedies, and seems to require a particular remedy, the presumption against curtailing courts' remedial discretion should be given significantly less weight.

\section{Judicial Precedent}

\section{The Supreme Court}

Supreme Court precedent supports reading the APA's text to require vacation of arbitrary agency action. In Citizens to Preserve Overton Park v. Volpe $e^{21}$ the Supreme Court held that "[i]n all cases agency action must be set aside if the action was 'arbitrary, capricious, an

217 See Tennessee Valley Authority, 437 U.S. at 195 (holding that "in our constitutional system the commitment of the separation of powers is too fundamental for us to pre-empt congressional action by judicially decreeing what accords with 'common sense and the public weel.' Our Constitution vests such responsibilities in the political branches.").

218 For a discussion of the distinction between primary and secondary legal rules, see H.L.A. HART, THE CONCEPT OF LAW 79 (1961) (explaining that "primary rules" require individuals "to do or abstain from certain actions" and, in contrast, "secondary rules," or "rules about rules," "confer powers" to create, alter, or apply primary rules). For a brief discussion of Hart's contrast between primary and secondary legal rules, see KenNeTH W. ABBOTT, ET AL., THE CONCEPT OF LEGALIZATION IN INTERNATIONAL ORGANIZATION 401, 403 (2000).

219437 U.S. 153.

220 Id at $193-95$.

221401 U.S. 402 (1971). 
abuse of discretion, or otherwise not in accordance with law' or if the action failed to meet statutory, procedural, or constitutional requirements." ${ }^{222}$ Similarly, in Camp v. Pitts, ${ }^{223}$ the Court held that "[i]f the agency's finding is not sustainable on the administrative record made, then the ... decision must be vacated and the matter remanded to (the agency) for further consideration." 224

Overton Park' $\mathrm{s}^{225}$ rejection of "'post hoc' rationalizations" ${ }^{226}$ for agency action provides additional support for the proposition that courts may not remand without vacating. In Overton Park, ${ }^{227}$ the Court held that the lower courts, which had based their review of the Secretary of Transportation's authorization of the use of federal funds to construct a highway through a public park on litigation affidavits, had acted illegally in violation of the APA's command that "the court shall review the whole record." ${ }^{228}$ Remanding without vacating, so that the agency may respond to deficiencies in its reasoning highlighted by the court, is in tension with the holding of Overton Park ${ }^{229}$ that "'post hoc' rationalizations ... have traditionally been found to be an inadequate basis for review." ${ }^{230}$ This principle, that courts should not conduct judicial review on the basis of post-hoc agency rationalizations finds consistent support in the case law. In Rodway v. USDA ${ }^{231}$ the court held that the Department of Agriculture's failure to provide a general statement of basis and purpose, as required by the APA, could not be cured by litigation affidavits because "as post hoc rationalizations, they are unacceptable substitutes for a contemporaneous basis and purpose statement and because they do not provide a 'whole record' to review." ${ }^{232}$ The court in Florida Power $\mathcal{E}$ Light Co. $v$. Lorian $^{233}$ held that " $[t]$ he focal point for judicial review should be the administrative record already in existence, not some new record made initially in the reviewing court."

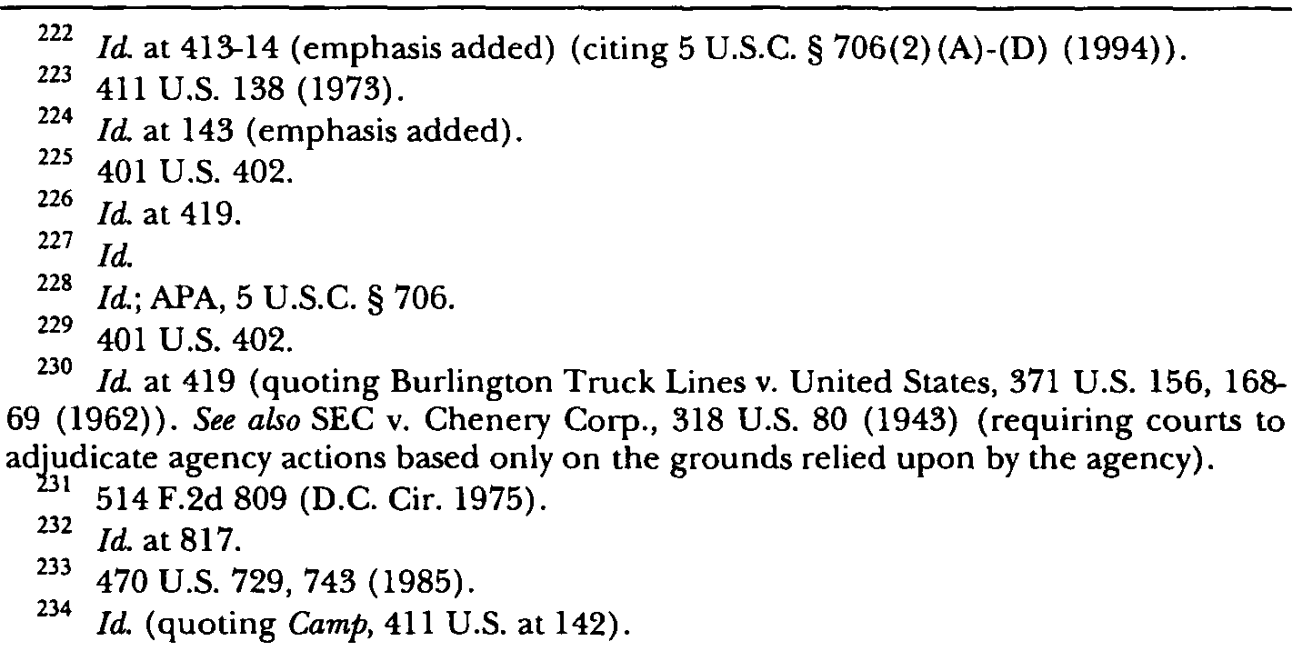


court is to apply the appropriate APA standard of review, 5 U.S.C. § 706 , to the agency decision based on the record the agency presents to the reviewing court." 235

These holdings cut against the legality of remanding to the agency so that the agency may respond to the court's concerns because such responses seem inherently post hoc and, on this account, illegitimate. These holdings also appear to address the argument that courts faced with insufficiently reasoned agency action, but unsure as to whether such action is arbitrary, need not make this determination on first pass. Because section 706 requires courts to conduct judicial review on the record developed by the agency and presented to the court, ${ }^{236}$ remanding to the agency to collect additional information is at odds with the APA's temporal requirement that judicial review be on the basis of the record-meaning the record as developed by the agency and presented to the court at the time the regulation is challenged and defended.

On the other hand, Florida Power ${ }^{237}$ might be cited for the proposition that the proper disposition, when the agency has provided a reviewing court with an insufficient basis for judicial review, is to remand to the agency for further elaboration:

If the record before the agency does not support the agency action, if the agency has not considered all relevant factors, or if the reviewing court simply cannot evaluate the challenged agency action on the basis of the record before it, the proper course, except in rare circumstances, is to remand to the agency for additional investigation or explanation. ${ }^{238}$

Two responses are relevant here. First, the Court's language does not make clear whether the regulations should be vacated. The Court only states that the action should be remanded to the agency, not that it should be remanded without being vacated. Second, this statement was made in the context of a discussion about whether a court should "conduct a de novo inquiry into the matter being re-

\footnotetext{
235

Id. at 743-44

See Vermont Yankee Nuclear Power Corp. v. Natural Resources Defense Counsel, 435 U.S. 519 (1978) ("We have made it abundantly clear before that when there is a contemporaneous explanation of the agency decision, the validity of that action must stand or fall on the propriety of that finding, judged, of course, by the appropriate standard of review.") (internal quotations omitted); Camp, 411 U.S. at 143 (validity of agency action must "stand or fall on the propriety of that finding .... If that finding is not sustainable on the administrative record made, then the decision must be vacated") (emphasis added). See also Chenery, 318 U.S. at 80.

${ }^{237} 470$ U.S. at 743.

238 Id. at 744.
} 
viewed and... reach its own conclusions based on such an inquiry." ${ }^{239}$ To say that a court should remand to the promulgating agency rather than conduct a de novo review is not to say that insufficiently reasoned agency action should not be vacated.

A second proposition confirmed by the Supreme Court is that the APA "established the maximum procedural requirements which Congress was willing to have the courts impose upon agencies in conducting rulemaking procedures." ${ }^{240}$ Vermont Yankee asserts a kind of APA fundamentalism: courts may only impose on agencies the procedural requirements outlined in the APA (or the agency's organic statute). Courts are not free to impose on agencies additional requirements beyond those provided for in the APA. On this account, remanding without vacating may represent a kind of extra-legal innovation, not authorized by the APA. For this reason it is impermissible. Courts may not "review agency proceedings to determine whether the agency employed procedures which were, in the court's opinion, perfectly tailored to reach what the court perceives to be the 'best' or 'correct' result." ${ }^{241}$ Remanding without vacating is an attempt to impose upon agencies extra-APA requirements. Remanding without vacating is nowhere explicitly authorized. The procedure is an attempt by courts to force agencies to collect and provide additional information not originally part of the record. Vermont Yankee prohibits this procedure because "the adequacy of the 'record'... turns on whether the agency has followed the statutory mandate of the Administrative Procedure Act," ${ }^{242}$ not on whether it takes into account every nuance perceived by the reviewing court.

In sum, courts reviewing agency action are authorized to set aside agency action when such action is arbitrary. When gaps are present in the agency's record, the court must determine whether these gaps are significant. If the agency has failed to answer critical questions or consider important alternatives, then the court is compelled by the APA to find such action insufficiently reasoned and therefore arbitrary. The court is also compelled to vacate such action. On the other hand, if the court finds that the record is less than perfect, but that such deficiencies are not fatal, then nothing in the APA permits courts to remand without vacating and, it appears, Vermont Yankee prohibits it.

\footnotetext{
239 Id.

240 Vermont Yankee, 435 U.S. at 524.

241 Id. at 546.

242 Id. at 547.
} 
2. The Lower Courts

Lower court precedent also supports reading the text of the APA to require vacation of arbitrary agency action. Several examples demonstrate the point. The court in Midtec Paper Corp. v. United States $^{243}$ noted that " $[\mathrm{p}]$ ursuant to the Administrative Procedure Act, courts are instructed always to 'hold unlawful and set aside actions, findings, and conclusions found to be . . arbitrary or capricious." "244 Even more recently, Judge Wald, in Petroleum Communications, Inc. $v$. $F C C$, ${ }^{245}$ stated that " $[\mathrm{w}]$ here the agency has failed to provide a reasoned explanation, or where the record belies the agency's conclusion, we must undo its action." ${ }^{246}$ Similarly, Judge Randolph, in Checkosky, ${ }^{247}$ stated that:

[o] nce a reviewing court determines that the agency has not adequately explained its decision, the Administrative Procedure Act requires the court-in the absence of any contrary statute-to vacate the agency action. The Administrative Procedure Act states this in the clearest possible terms. ... [A] "reviewing court" faced with an arbitrary and capricious agency decision "shall"-not may- "hold unlawful and set aside" the agency action. ${ }^{248}$

Judge Randolph further explained that " $[\mathrm{n}]$ o statute governing judicial review of agency action permits . . a [remand without vacating] disposition and the controlling statute-5 U.S.C. $\$ 706$ (2) (A)flatly prohibits it." 249 Finally, Judge Randolph concluded that "[i]n decision after decision, we have held that under $\$ 706(2)(\mathrm{A})$, the reviewing court 'must' set aside [arbitrary] agency action." ${ }^{250}$ By remanding without vacating arbitrary agency action and allowing such regulations to remain in effect while on remand, courts seem to contravene the text of the APA requiring that such regulations be held unlawful and set aside. In the words of Judge Randolph: "To order only a remand despite the APA's mandate is to act in stubborn defiance of the law."251

243

244

245

246

247

248

249

250

251

857 F.2d 1487 (D.C. Cir. 1988).

Id. at 1497 (emphasis added) (citing 5 U.S.C. $\S 706(2)$ (A)).

22 F.3d 1164 (D.C. Cir. 1994).

Id. at 1172 (emphasis added).

23 F.3d 452 (D.C. Cir. 1994).

Checkosky, 23 F.3d at 491 (footnotes omitted).

Id. at 490.

Id. at 492 .

Id. at 493 . 


\section{CONCLUSION}

In the last decade courts reviewing agency action have increasingly opted to remand the challenged regulation to the agency without vacating. This trend is likely to continue or accelerate. This Article argues that remanding without vacating arbitrary or insufficiently reasoned agency action is unlawful. After arguing that the ambiguous practical benefits of remanding without vacating do not justify brushing the legal arguments aside, this Article concludes that the text of the APA, along with the legislative history, statutory purpose, canons of construction, and judicial precedent demonstrate the illegality of remanding without vacating. 